\title{
Top-down release of mesopredatory fish is a weaker structuring driver of temperate rocky shore communities than bottom-up nutrient enrichment
}

\author{
Patrik Kraufvelin ${ }^{1}$. Hartvig Christie ${ }^{2}$ Janne Kim Gitmark ${ }^{2}$
}

Received: 6 June 2019 / Accepted: 5 February 2020 / Published online: 3 March 2020

(c) The Author(s) 2020

\begin{abstract}
Ecological impacts of top-down trophic cascades in combination with bottom-up nutrient enrichment are increasingly being reported. Such effects may be triggered by decline in the abundance and size of piscivore fish leading to a release of smallersized mesopredatory fish that are capable of reducing mesograzers and their buffering herbivorous effects, thus intensifying eutrophication symptoms. Hitherto, such mesopredator release has not been studied in controlled manner in macroalgaldominated rocky shore communities. This study utilised twelve littoral mesocosms in southeastern Norway to investigate the impact of increased nutrient levels and increased abundance of the mesopredatory goldsinny wrasse (Ctenolabrus rupestris) over 6 months, from spring (April) to autumn (October). The study mainly revealed typical eutrophication responses in both July and in October with nutrient enrichment leading to more ephemeral algae and less perennial Fucacean and red macroalgae. Significant responses to the addition of mesopredatory fish alone or with nutrients in combination were clearly fewer in July and almost non-existent in October. Mesopredatory fish reduced the number of some mesograzers, but not others, and some herbivores even benefitted. Few joint effects occurred between fish and nutrients and the anticipated negative consequences for perennial macrophytes were largely absent; the possible reasons for these observations are discussed in depth. Curiously, the presence of mesopredatory fish seems to favour some canopy-forming macrophytes. This last finding warrants further investigation as the labrid fishery in coastal waters of southern Norway and western Sweden is increasing and a too heavy reduction of mesopredators may have its own unforeseen ecosystem implications.
\end{abstract}

\section{Introduction}

Extensive community changes also named regime shifts (Scheffer et al. 2001), for instance from kelp beds to dominance of filamentous algae, are known to occur in the south and west coast of Norway (Moy and Christie 2012). Concurrently, changes in composition of seaweed beds and eelgrass distribution have been reported from the Swedish part

Responsible Editor: F. Bulleri.

Reviewed by P. Brooks and an undisclosed expert.

Patrik Kraufvelin

patrik.kraufvelin@slu.se

1 Department of Aquatic Resources, Institute of Coastal Research, Swedish University of Agricultural Sciences, Skolgatan 6, 74242 Öregrund, Sweden

2 Norwegian Institute for Water Research (NIVA), Gaustadalléen 21, 0349 Oslo, Norway of Skagerrak in the northeastern North Sea (Eriksson et al. 2002; Baden et al. 2003, 2012; Moksnes et al. 2008). Previously, such changes have mainly been related to eutrophication (Cloern 2001; Gorgula and Connell 2004; Worm and Lotze 2006, Valiela et al. 1997). Still, despite many years of ongoing eutrophication, macrophytic community changes have been delayed (Andersson 1996); for instance some dramatic shifts from perennial macroalgae to turf communities in Norway did not occur before a documented decline in nutrient load (Frigstad et al. 2013). Therefore, it seems natural that additional stressors must also contribute to reduce the community resistance to eutrophication (Korpinen et al. 2007; Araujo et al. 2016; Rothäusler and Jormalainen 2016; Kraufvelin et al. 2018; Bergström et al. 2019). Corresponding changes in the relative dominance of different functional groups of benthic primary producers are also well known from other marine systems globally. These changes have partly been explained by predation release on lower trophic levels due to fisheries-related depletion of large piscivorous fish (Pauly et al. 1998; Daan et al. 2005; Britten et al. 2014). 
A combination of eutrophication, climate change, overfishing and deterioration of fish spawning habitats are thus currently suspected to be responsible for some of these regime shifts in temperate coastal waters (Jackson et al. 2001; Harley et al. 2006; Spencer et al. 2011; Chemello et al. 2018; Kraufvelin et al. 2018). In the northeast Atlantic and in the Baltic Sea, weakened top-down effects due to decreased abundance and size of piscivore fish have been demonstrated (Moksnes et al. 2008; Eriksson et al. 2009, 2011; Sieben et al. 2011; Östman et al. 2016). Here, overfishing and a lower abundance of large coastal cod are suspected to lead to a release of mesopredators (smaller-sized fish, crabs and shrimps) that are capable of reducing the number of mesograzers (such as small gastropods, and isopod and amphipod crustaceans). Thereby, the mesopredators also decrease the buffering herbivorous effects of mesograzers on opportunistic macroalgae that have benefitted from nutrient enrichment (Moksnes et al. 2008; Östman et al. 2016; Donadi et al. 2017) and that may harm perennial macrophyte performance and/or recruitment (Kraufvelin et al. 2006b, 2007; Baden et al. 2012). The actual consequences for perennial vegetation, however, will depend on which mesopredators and mesograzers that are dominant in the studied system, their feeding biology and their interactions (Christie et al. 2009; Duffy et al. 2013).

Currently, the coastal food webs in southern Norway and western Sweden are under change. Gjøsæter and Paulsen (2004) state that the decrease in size and abundance of the top predator coastal cod has resulted in an increase in abundance of smaller fish such as labrids and gobids. By gillnet fishing in different habitats, Moy et al. (2007) showed labrids, and particularly the goldsinny wrasse, Ctenolabrus rupestris, to be the most abundant fish species in rocky shore communities dominated by kelps or other macroalgal vegetation. Similar results were presented by Bergström et al. (2016) and Kraufvelin et al. (2017) for both the goldsinny and for the corkwing wrasse, Symphodus melops, from fyke net fishing on the Swedish part of the Skagerrak coast. The wrasses are found to prey on a variety of small grazers in seaweeds (Norderhaug et al. 2005) and may thus contribute to reducing herbivory/grazing and hence the community control imposed by small-sized consumer species. This may in turn result in community changes if the number of mesopredatory fish change (increase in abundance, but also if they decrease). A raised interest in the use of wrasses as cleaners of salmon lice in Norwegian fish farms (Darwall et al. 1992; Tully et al. 1996; Skiftesvik et al. 2014) could also lead to overfishing of these labrids (Halvorsen et al. 2017; Olsen et al. 2018). As such, the wrasse fishery may impact rocky shore communities by causing decreased abundance of the targeted wrasse species and even local extinction. As a result, both increase and decrease in the amount of mesopredatory fish and their ecological influence on shallow hard bottoms are at present of great interest, ecologically, scientifically and for environmental management purposes.

The alternatives for controlled investigations of top-down and bottom-up influences under field-like conditions are usually scarce. Sometimes, researchers may have access to areas with predators and non-predator control areas (see Baden et al. 2012; Duffy et al. 2013) or they may perform complex field experiments using cages (Moksnes et al. 2008; Donadi et al. 2018) or controlled reduction of grazers (Duffy et al. 2015). These studies above focusing on brackish water macrophytes and marine seagrasses conclude that reduced grazing on turf algae is an important factor which ultimately causes reduction in the distribution of perennial macrophytes. Corresponding experiments on the effects of wrasse predation on mesograzers which also consider consequences on macroalgal beds have so far not been carried out. Indeed, such studies can be challenging to design and run with controlled nutrient enrichment in the field at the shore scale. These challenges may be faced, however, using the twelve rocky shore mesocosms available at Solbergstrand in southeastern Norway. Since the mid-1990s, the Solbergstrand mesocosms have been used for controlled studies of the effects of nutrient enrichment (Kraufvelin et al. 2002; 2006a; b; Bokn et al. 2002, 2003; Karez et al. 2004; Díaz et al. 2012) and the combination of nutrient enrichment and reduced wave action (Kraufvelin 2007; Kraufvelin et al. 2010) and the mesocosms have functioned well and delivered reliable research results.

The aim of the present study was to use the Solbergstrand mesocosms in a strictly controlled manner to study the effects of two factors, nutrient enrichment and presence/absence of mesopredatory fish, on rocky shore macroalgal communities. The central hypotheses were that nutrient enrichment and predation by mesopredatory fish, alone and/or in combination, will have significant effects on rocky shore community structure and function. More specifically, a central objective was to examine whether nutrient enrichment and predation by mesopredatory fish were causing shifts from dominance of perennials to dominance of ephemeral algae, as anticipated in many scientific reports. Another central objective was to study the extent to which certain mesograzer groups such as amphipods, isopods and gastropods were affected by bottomup nutrient enrichment and by top-down mesopredatory fish. Figure 1 presents a summarised conceptual model of the central hypotheses of this study.

\section{Material and methods}

\section{Description of the Solbergstrand mesocosms and treatment factors}

The experiments took place in twelve outdoor concrete mesocosms at Marine Research Station Solbergstrand (59 37' 


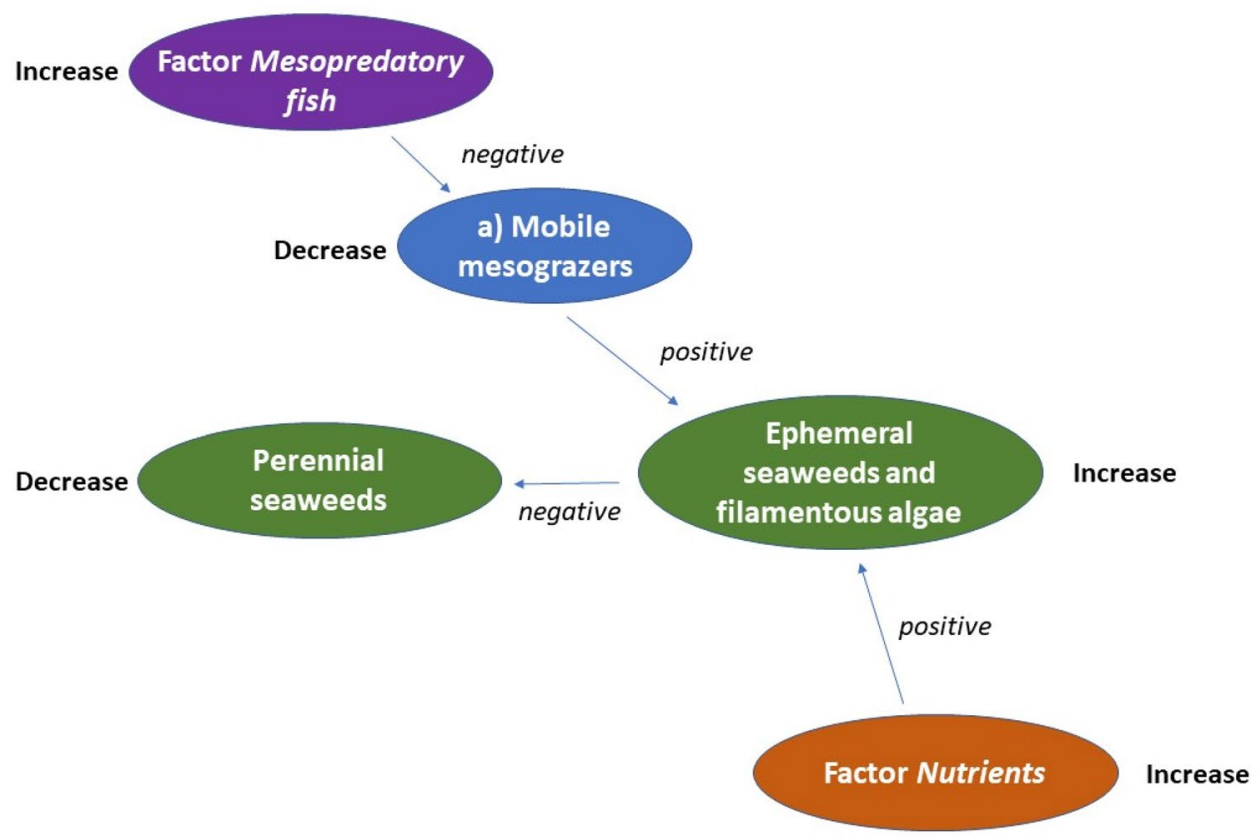

Fig. 1 Conceptual model of the hypotheses for this study. When nutrients increase (in connection with eutrophication), ephemeral algae are favoured in a bottom-up way. Reduced densities of top predators (not shown in the figure) will favour (release) smaller mesopredatory fish that will reduce densities of mobile grazers (amphipods and gastropods, etc., this is marked with $\mathbf{a}$ in the figure) in a top-down

$\mathrm{N}, 10^{\circ} 39^{\prime} \mathrm{E}$ ) by the outer Oslofjord (southeastern Norway) in 2012. These unique mesocosms contained rocky shore macroalgal and macrofaunal communities that had been established over 2 years preceding the experiment. Each mesocosm had a wave machine providing 18 strokes per minute and generating an effective wave amplitude of $11 \mathrm{~cm}$ corresponding to a wind force of approximately $5 \mathrm{~m} / \mathrm{s}$, which is normal for relatively sheltered coastal areas. Wave energy is important, since it influences the nutrient uptake and the resistance and resilience of perennial macroalgae as well as the resulting community structure and function (Kraufvelin 2007; Kraufvelin et al. 2010). Each mesocosm had a tide regulator lowering and raising the outlet pipes regularly and providing synchronized tidal cycles in the mesocosms with an amplitude of $36 \mathrm{~cm}$ mimicking natural cycles locally. Each mesocosm tank was $4.75 \times 3.65 \mathrm{~m}$ at surface level and contained $12 \mathrm{~m}^{3}$ of water at high tide, when about $1.3 \mathrm{~m}$ deep, and $6 \mathrm{~m}^{3}$ of water at low tide. The mesocosms were constantly fed with water from $1 \mathrm{~m}$ depth from the Oslofjord with flow rates of $4 \mathrm{~m}^{3} \mathrm{~h}^{-1}$ and a short mean water residence time of 2-3 h ensuring ambient water temperatures and salinities.

Littoral communities were initiated in 2010 by transferring small boulders with associated macroalgae and fauna from the fjord to four steps built at one side (the sunny eastern one) of each mesocosm and representing different way and cause a declining grazer activity that will favour fast growing filamentous algae. The synergetic favouring of ephemeral algae from nutrients and reduced grazing will lead to a decrease of perennial seaweeds like Fucaceans (here) and kelps. Alternative interaction pathways have not been included into the original hypotheses

vertical zones of a rocky shore (for a schematic view of a mesocosm see Fig. 1 in either Kraufvelin et al. 2010 or in Díaz et al. 2012). On the uppermost two steps (representing the intertidal zone), the perennial macroalgal canopy was dominated by Fucus vesiculosus and on subsequent steps downwards in the water (in the subtidal), Fucus serratus and various species of red algae dominated. In the rest of the bottom area, various species of red, brown and green macroalgae were common. On the bottom, two plastic boxes (each $30 \times 50 \mathrm{~cm}$ ) with sand and seven shoots of eelgrass Zostera marina in each box were introduced to each mesocosm at the start of the experiment in the beginning of April 2012. Eelgrass is part of the shallow sublittoral macrophyte landscape and reacts to increased growth of filamentous algae in a similar way as perennial macroalgae (see Moksnes et al. 2008; Baden et al. 2012). The density of eelgrass is patchy in the field area outside the mesocosms and the applied initial density in the mesocosm study was deemed realistic. In addition to the original introduction of organisms described above, the inflowing water acted as a continuous source for spores and larvae throughout the experimental period.

Transplantation and natural community development have in previous studies resulted in all mesocosms containing rich floras and faunas resembling that of natural rocky shores of the fjord outside before the start of experimental treatment periods (Bokn and Lein 1978; Bokn et al. 2002, 
2003; Kraufvelin et al. 2002, 2006b, 2010). After each individual experiment, the communities have been allowed to recover their structure and function and boulders with flora and fauna have been reorganised (evened out) to achieve similar initial conditions in all experimental units (see e.g. Kraufvelin 2007 and Díaz et al. 2012). For this specific study, in April 2012, the boulders with algae were organised to form a dense macroalgal association over $2 / 3$ of the mesocosm steps. These vegetated areas were present at each side of the steps, leaving the central 1/3 with boulders from the sea without macroalgal vegetation to form cleared areas to imitate typical scenarios, such as after a heavy storm event or winter-time ice scouring. At high latitudes, macroalgal beds may be heavily disturbed by physical factors as ice scouring (Nilsson et al. 2004) and storms (Micheli et al. 2016). The concrete bottom surfaces of the central $1 / 3$ of the mesocosm steps were also scraped mechanically at the start of the experiment to offer pioneer benthic areas for colonisation during the course of the experiment which in previous experiments has been shown to speed up responses to the treatment factors. For this purpose, the slower and delayed responses to nutrient enrichment reported by Bokn et al. (2003) and by Kraufvelin et al. (2006b), when no scraping was used, can be compared with the quicker responses reported by Kraufvelin (2007), Kraufvelin et al. (2010) and Díaz et al. (2012) utilizing scraping.

The twelve mesocosms were arranged in a fully factorial design where two factors could be tested separately and in combination with proper replication. The factor Nutrients was applied to six mesocosms with automatic dosing equipment ( $32 \mu \mathrm{mol} \mathrm{l}^{-1}$ nitrogen and $2 \mu \mathrm{mol}^{-1}$ phosphorus above background fjord levels), whereas the remaining six mesocosms received just fjord water. Nutrients were added as a mixture which consisted of $14.3 \mathrm{~mol} \mathrm{~N}$ as $\mathrm{NH}_{4} \mathrm{NO}_{3}$ and $0.9 \mathrm{~mol} \mathrm{P}$ as $\mathrm{H}_{3} \mathrm{PO}_{4}$ and had an N/P mol ratio of $16 / 1$ (Kraufvelin et al. 2010). Nutrient treatment levels used corresponded with concentrations recorded in eutrophic areas locally (Kristiansen and Paasche 1982) and globally (Cloern 2001) and similar levels have been used previously in studies using these mesocosms (Bokn et al. 2003; Kraufvelin et al. 2006a, b, 2010; Díaz et al. 2012). The other major factor, Fish, which represents the cascade effect due to depleted abundance of large piscivorous fish, was tested by introducing 30 individual goldsinny wrasse (C. rupestris) with lengths that ranged between 12 and $14 \mathrm{~cm}$ into each of six mesocosms, while the remaining six mesocosms were kept without fish. The designs with 30 (2.5-4 fish individuals per $\mathrm{m}^{2}$ of bottom area or $\mathrm{m}^{3}$ of water volume, dependent of tidal level) or no fish in the experiments were based on densities from field observations or used to represent scenarios where wrasses are heavily fished (reaching down to 0). By this design, the factors Nutrients and Fish were crossed and applied to the twelve mesocosms resulting in three mesocosms with elevated levels of both nutrients and fish, three mesocosms with elevated nutrient levels and no fish, three mesocosms with ambient nutrient levels and elevated levels of fish, and three mesocosms with ambient nutrient levels and no fish $(3 \times 2 \times 2=12)$. All basins were supplied with instruments continuously measuring and logging temperature, salinity and $\mathrm{pH}$. Nutrient addition started in April, and fish were introduced in late May; this was because the goldsinny wrasse is less active during winter and difficult to catch before late spring. Fish were "refilled" in the fish mesocosms in late July, to ensure an optimal number of mesopredators of around 30 individuals in each of the fish treatments (which later proved successful judging from the final number surviving until October, see the Results section).

\section{Sampling of mesocosm communities}

In April, basic background measurements of the coverage and abundance of dominating macroalgal and macrofaunal species were made. In late July (after 3 months of experimentation), a taxonomically more detailed sampling was carried out, and the last detailed sampling took place in mid-October (after 6 months of experimentation). In July and October, all taxa were determined to the lowest possible level and diversity indices, Margalef species richness and Shannon-Wiener diversity, were calculated separately for macroalgae and for macrofauna.

The cover of benthic organisms on the mesocosm steps was a central response variable for the purposes of this study. In April, before the start of the experiments, the rough estimates of percentage cover focused on Fucus serratus, Fucus vesiculosus and grouped together filamentous algae into the classes brown, red and green to get basic information of the background situation. In July and October, the percentage cover of all the different species found was estimated in 12 $(40 \times 40 \mathrm{~cm})$ frames. This was naturally the case for all species of macroalgae and for larger macrofauna such as Littorina spp., crabs, starfish, mussels and barnacles. Counts of macrofauna individuals were later translated into percentage cover for use in the analyses. To compare development on different vertical levels of littoral communities of similar initial origin, and to compare with earlier studies, in each of the areas closest to the side walls of each mesocosm, one set of $1 \times 4$ vertical frames $(40 \times 40 \mathrm{~cm})$ were used on established canopy algal communities and another set of $1 \times 4$ vertical frames were used in the cleared areas in the centre of each mesocosm step. These subsamples were later pooled for the statistical analyses. Due to time and resource constraints, a full detailed sampling which included the mesocosm walls and bottom areas was not possible and would have resulted in additional disturbances on the mesocosm communities.

Smaller mobile mesograzers on the steps were sampled by use of artificial substrates (see Kraufvelin et al. 2002, 
2006a, b, 2010) followed by identification and counting. Four artificial substrates, each consisting of three $100 \mathrm{~cm}$ long ropes, one stone and a petri dish tied together with rubber bands, were placed on each of two depth levels (one intertidal step and one subtidal step) in each basin after which colonisation was allowed for $48 \mathrm{~h}$. These substrates have proven capable of capturing an intermediate fraction of the animals normally present in the dominating algal types (brown, red and green algae) in the mesocosms (Kraufvelin et al. 2002). At the sampling in July, amphipods, isopods, smaller gastropods and other animals were examined and identified alive and released back into the mesocosms. In October, all corresponding fauna samples were put on ethanol (70\% mixture of ethanol and seawater) and later examined to the lowest possible taxonomic level under the microscope in the laboratory. All macrofauna samples taken from the same mesocosm were pooled for the statistical analyses.

Mobile mesograzers (freely swimming species and animals associated with floating algae) were also examined from the outlet pipes, to which fine nets were fastened to collect everything leaving the mesocosms for $1 \mathrm{~h}$ during the day and for $1 \mathrm{~h}$ during the night, 2 subsequent days and nights in July and in October, respectively. For a thorough description of this methodology, see Christie and Kraufvelin (2004). These samples were analysed alive in July, whereas preserved samples from October were analysed to the lowest possible taxonomic level under the microscope.

Community function was estimated based on total production/respiration by registering changes in $\mathrm{pH}$ levels when the water inlet was closed down for $2 \mathrm{~h}$ during full daylight and for $2 \mathrm{~h}$ during dark night hours (Kraufvelin et al. 2010) on 2 subsequent days and nights in July and in October, respectively. The changes in $\mathrm{pH}$ over time can be used for calculation of the total amount of carbon that is taken up from or released to a closed water body, as long as the total alkalinity, the temperature and the salinity of the water body are known (Hansson 1973; Almgren et al. 1975). Previously, Oviatt et al. (1986) used changes in $\mathrm{pH}$ levels in mesocosms to estimate production and respiration and reported a good synchronicity with oxygen measurements, which are more commonly used for these purposes (see e.g. Noël et al. 2010). More details about this method and its use in Solbergstrand mesocosm experiments can be found in Kraufvelin et al. (2010).

At the end of the mesocosm experiments in October, all remaining goldsinny wrasses were collected, counted, sizedetermined, killed and frozen and their stomach content was later examined under the microscope in the laboratory.

The applied sampling techniques and methodologies in these mesocosms have been in use since the 1990s and have been widely published with replicated mesocosms developing quite similarly (see e.g. Bokn et al. 2002, 2003; Kraufvelin et al. 2002, 2006a, b, 2010; Barrón et al. 2003, Christie and Kraufvelin 2004; Karez et al. 2004; Kraufvelin 2007; Díaz et al. 2012).

\section{Statistical data analyses}

The different study questions (hypotheses) were tested by two-way PERMANOVAs for multivariate data and by twoway factorial ANOVAs for univariate variables, where the strengths of the overall community's and individual species' responses to the fixed main factors Nutrients $(\mathrm{N})$ and Fish (F) and their interaction term could be investigated (Underwood 1997). Using abundance data of all macroalgal and macrofaunal species, respectively, overall patterns of variation in the twelve mesocosms were visualized with principal coordinates analysis (PCO) based on Bray-Curtis similarities (Anderson et al. 2008). The direction and intensity of the correlations of the main species with the first two PCO axes were then shown by vector overlays on the PCO plot.

All multivariate data were analysed by non-parametric multivariate techniques available in the PRIMER statistical package with the PERMANOVA extension (Clarke 1993; Anderson 2005; Clarke and Gorley 2006; Anderson et al. 2008), whereas the univariate data were analysed by the software GMAV5 (Underwood \& Chapman 1997). Alpha levels were set at 0.05 . Before running the multivariate analyses, data were transformed using square-root transformation to balance the influence between more dominant or rare species/taxa. Before running parametric univariate tests, the normality was checked by Kolmogorov-Smirnov's test and homogeneity of variances by Cochran's C-test. To homogenise variances, it was sometimes necessary to use squareroot or logarithmic transformations. For significant interactions, SNK tests were applied a posteriori to verify which levels of the factors that were responsible for the observed differences.

\section{Results}

\section{Physical and chemical water properties}

Water temperature and salinity were recorded automatically on an hourly basis through the experiment. The temperature was about $4{ }^{\circ} \mathrm{C}$ at the beginning of the experiment (in early April), raised to $8{ }^{\circ} \mathrm{C}$ in early May, $14{ }^{\circ} \mathrm{C}$ in early June and reached a maximum at about $19{ }^{\circ} \mathrm{C}$ in July-August, whereafter it decreased to $17^{\circ} \mathrm{C}$ in September and further to about $13{ }^{\circ} \mathrm{C}$ at the end of the experiment in early October. Salinity was about 29 practical salinity units (psu) at the start, then decreased gradually with increased freshwater runoff in spring and early summer to 23 psu in May and down to 17 psu in June and July. Salinity increased again from August on and was 23 psu at the end of the experiment in October. 
The intertidal and shallow subtidal organisms in the Oslofjord region are used to such levels of seasonal variation in environmental conditions.

\section{Responses in community structure on mesocosm steps (cover of macroalgae and macrofauna)}

Figure 2 shows the development for some central response variables over time (April - October). In April, before the initiation of the treatment factors, there were no significant differences in the cover of Fucaceans, in the cover of filamentous algae lumped together into the three classes brown, green and red algae and nor in total cover of organisms including all macroalgae and sessile and slowly moving macrofauna. The cover of the dominating brown macroalga Fucus serratus was quite stable over the experimental period at low nutrient and low fish levels, whereas it slightly increased at low nutrient and high fish levels and clearly

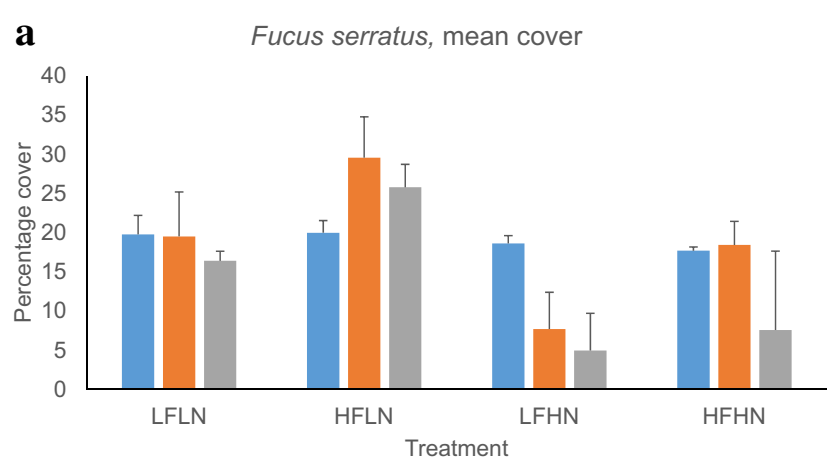

April $\quad$ July $=$ October

b

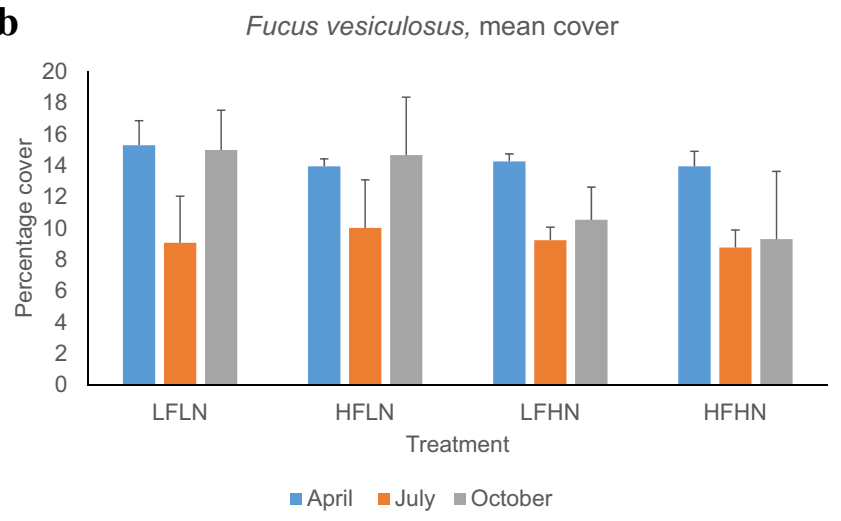

c

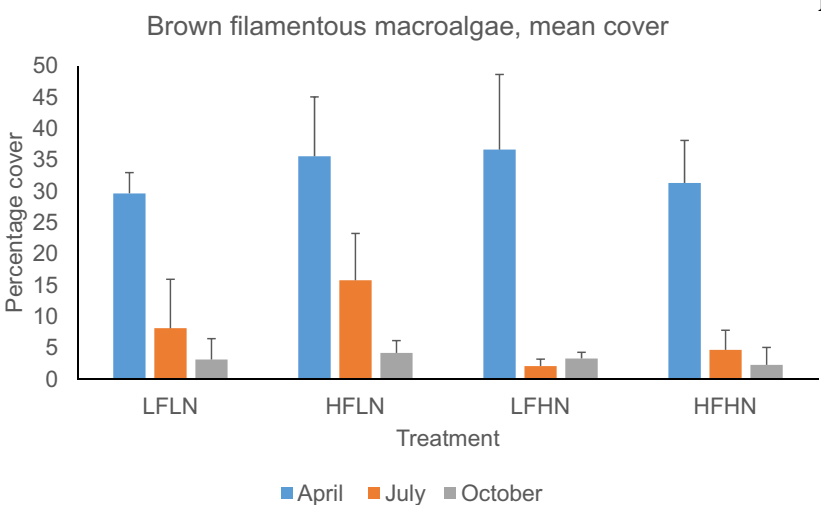

Fig. 2 Average cover $(+\mathrm{SD})$ in the mesocosms of dominating Fucaceans, filamentous macroalgae grouped into classes and total organisms at the start of the experiment in April and after 3 months of experimentation in July and after 6 months of experimentation in

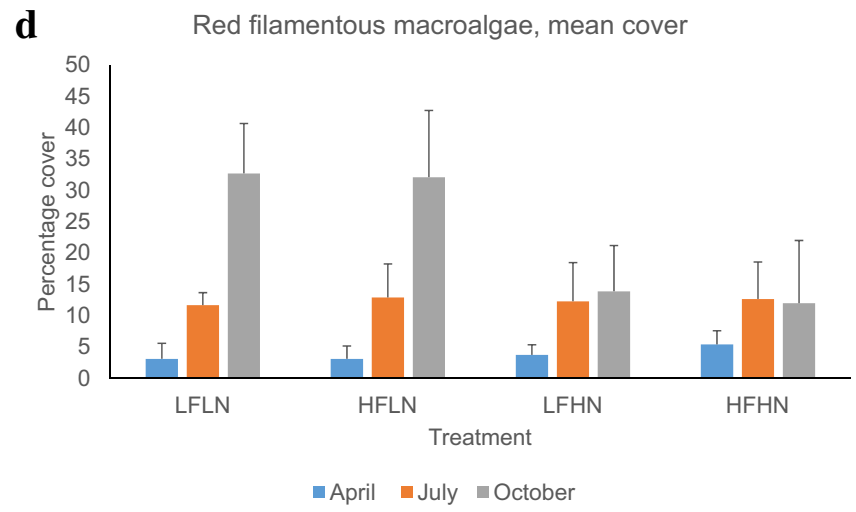

e

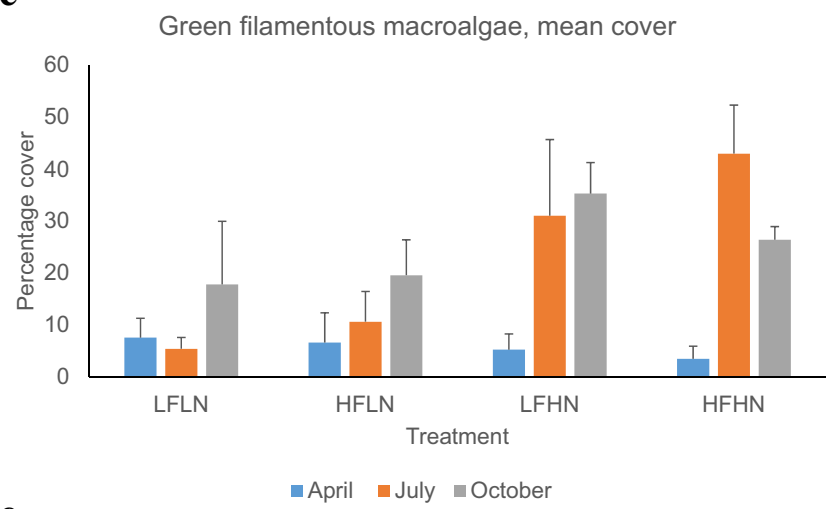

f

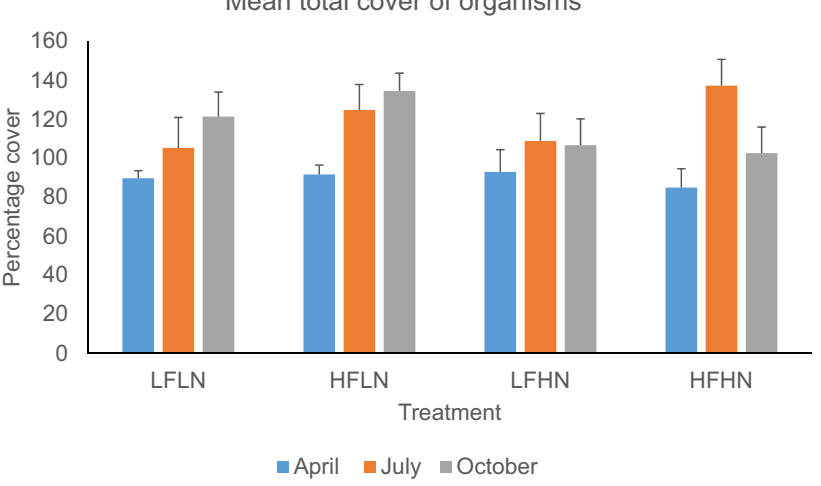

October: a Fucus serratus, b Fucus vesiculosus, c filamentous brown algae, d filamentous red algae, e filamentous green algae, $\mathbf{f}$ total organisms 
decreased at both high nutrient level treatments and more rapidly so in the absence of mesopredatory fish. Thus, for $F$. serratus there was in July a significantly higher cover at low nutrient levels and also in the presence of mesopredatory fish, while in October the cover of $F$. serratus was higher at low nutrient levels (Tables 1-2, Fig. 2a). For Fucus vesiculosus there were no other significant differences among treatments during the experimental period than a slightly higher cover at low nutrient levels in October (Table 2, Fig. 2b). The cover of filamentous algae varied considerably among seasons (Fig. 2c-e) and due to nutrient enrichment, but not due to mesopredatory fish. Brown filamentous algae were significantly more abundant at low nutrient levels in July (Table 1, Fig. 2c), whereas red filamentous algae were significantly more abundant at low nutrient levels in October
(Table 2, Fig. 2d). For green filamentous algae the cover was significantly higher at high nutrient levels in both July and in October (Tables 1-2, Fig. 2e). With regard to total cover of organisms, this response variable increased over time, with the exception of high nutrient treatments. Total cover of organisms was significantly higher in the presence of mesopredatory fish in July and significantly higher at low nutrient levels in October (Tables 1-2, Fig. 2f).

Multivariate PCO ordinations on macroalgal cover data using square-root transformed values on all four steps and with established and cleared areas pooled showed distinct differences in species composition for the main factor Nutrients in both July (multivariate two-way PERMANOVA Pseudo- $F_{1,8}=5.59, p=0.002^{* *}$, Table 1, Fig. 3a) and in October (Pseudo- $F_{1,8}=6.34, p=0.003^{* *}$, Table 2, Fig. 3b).

Table 1 The main significant $p$ values from July (after 3 months of experimentation)

\begin{tabular}{|c|c|c|c|}
\hline Variable & Nutrients (bottom-up) & Fish (top-down) & $\begin{array}{l}\text { Nutrients } \times \text { Fish } \\
\text { (bottom-up and top- } \\
\text { down) }\end{array}$ \\
\hline \multicolumn{4}{|l|}{ Cover on mesocosm steps } \\
\hline Macroalgal spec. composition & $p=0.002$ & - & - \\
\hline Total cover of organisms & - & $p=0.019(\mathrm{LF}<\mathrm{HF})$ & - \\
\hline Cover of brown filamentous macroalgae & $p=0.030(\mathrm{LN}>\mathrm{HN})$ & - & - \\
\hline Cover of green filamentous macroalgae & $p<0.001(\mathrm{LN}<<<\mathrm{HN})$ & - & - \\
\hline Margalef macroalgal cover & $p=0.022(\mathrm{LN}>\mathrm{HN})$ & - & - \\
\hline Fucus serratus cover & $p=0.003(\mathrm{LN}>>\mathrm{HN})$ & $p=0.005(\mathrm{LF}<<\mathrm{HF})$ & - \\
\hline Fucus juveniles cover & $p=0.027(\mathrm{LN}>\mathrm{HN})$ & - & - \\
\hline Ulva intestinalis cover & $p<0.001(\mathrm{LN}<<<\mathrm{HN})$ & - & - \\
\hline Ulva lactuca cover & $p<0.001(\mathrm{LN}<<<\mathrm{HN})$ & - & - \\
\hline Porphyra umbilicalis cover & $p<0.001(\mathrm{LN}<<<\mathrm{HN})$ & - & - \\
\hline Balanus improvisus cover & - & - & $p=0.018$ (SNK tests) \\
\hline \multicolumn{4}{|c|}{ Macrofauna in artificial substrates on pooled steps } \\
\hline Species composition & $p=0.017$ & $p=0.004$ & - \\
\hline Total abundance & - & $p=0.037(\mathrm{LF}<\mathrm{HF})$ & - \\
\hline Idotea spp. abundance & $p=0.034(\mathrm{LN}<\mathrm{HN})$ & - & - \\
\hline Hyale nilssoni abundance & $p=0.015(\mathrm{LN}<\mathrm{HN})$ & & - \\
\hline Gammarus spp. abundance & & $p=0.009(\mathrm{LF}<<\mathrm{HF})$ & - \\
\hline Lacuna spp. abundance & $p=0.002(\mathrm{LN}<<\mathrm{HN})-$ & - & $p=0.029$ (SNK tests) \\
\hline \multicolumn{4}{|l|}{ Outlet macrofauna } \\
\hline Species composition & - & $p=0.005$ & - \\
\hline Total abundance day & - & $p=0.004(\mathrm{LF}>>\mathrm{HF})$ & - \\
\hline Total abundance night & - & $p=0.002(\mathrm{LF}>>\mathrm{HF})$ & - \\
\hline Amphipods day & $p=0.025(\mathrm{LN}<\mathrm{HN})$ & $p=0.008(\mathrm{LF}>>\mathrm{HF})$ & - \\
\hline Amphipods night & - & $p=0.012(\mathrm{LF}>\mathrm{HF})$ & - \\
\hline Lacuna spp. day & - & $p=0.043(\mathrm{LF}>\mathrm{HF})$ & - \\
\hline \multicolumn{4}{|l|}{ Mesocosm metabolism } \\
\hline Carbon production day & $p=0.032(\mathrm{LN}<\mathrm{HN})$ & - & - \\
\hline Carbon respiration night & $p<0.001(\mathrm{LN}<<<\mathrm{HN})$ & - & - \\
\hline
\end{tabular}

Differences in species composition were tested for by two-way PERMANOVA. All other differences were tested for by two-way ANOVA $L N$ low nutrient levels, $H N$ high nutrient levels, $L F$ low fish levels, $H F$ high fish levels 
Table 2 The main significant $p$ values from October (after 6 months of experimentation)

\begin{tabular}{|c|c|c|c|}
\hline Variable & Nutrients (bottom-up) & Fish (top-down) & $\begin{array}{l}\text { Nutrients } \times \text { Fish } \\
\text { (bottom-up and top- } \\
\text { down) }\end{array}$ \\
\hline \multicolumn{4}{|l|}{ Cover on mesocosm steps } \\
\hline Macroalgal spec. composition & $p=0.003$ & - & - \\
\hline Macrofaunal spec. comp & $p=0.036$ & - & - \\
\hline Total cover of organisms & $p=0.011(\mathrm{LN}>\mathrm{HN})$ & - & - \\
\hline Cover of green filamentous macroalgae & $p=0.025(\mathrm{LN}<\mathrm{HN})$ & - & - \\
\hline Cover of red filamentous macroalgae & $p=0.006(\mathrm{LN}>>\mathrm{HN})$ & - & - \\
\hline Fucus serratus cover & $p=0.002(\mathrm{LN}>>\mathrm{HN})$ & - & - \\
\hline Fucus vesiculosus cover & $p=0.033(\mathrm{LN}>\mathrm{HN})$ & - & - \\
\hline Fucus juveniles cover & $p=0.037(\mathrm{LN}>\mathrm{HN})$ & - & - \\
\hline Ulva intestinalis cover & $p=0.012(\mathrm{LN}<\mathrm{HN})$ & $p=0.032(\mathrm{LF}>\mathrm{HF})$ & $p=0.032(\mathrm{SNK}$ tests $)$ \\
\hline Ulva lactuca cover & $p=0.044(\mathrm{LN}<\mathrm{HN})$ & - & - \\
\hline Spongomorpha aerug. cover & $p<0.001(\mathrm{LN}<<<\mathrm{HN})$ & - & - \\
\hline Porphyra umbilicalis cover & $p<0.001(\mathrm{LN}>>>\mathrm{HN})$ & - & - \\
\hline Polysiphonia fucoides cover & $p=0.003(\mathrm{LN}>>\mathrm{HN})$ & - & - \\
\hline Ceramium strictum cover & $p=0.025(\mathrm{LN}>\mathrm{HN})$ & - & - \\
\hline Littorina littorea juveniles & $p=0.002(\mathrm{LN}<<\mathrm{HN})$ & - & - \\
\hline Electra pilosa cover & $p<0.001(\mathrm{LN}>>>\mathrm{HN})$ & - & - \\
\hline \multicolumn{4}{|l|}{ Macrofauna in artificial substrates on steps } \\
\hline Species composition & $p=0.005$ & - & - \\
\hline Shannon-Wiener diversity & $p=0.001(\mathrm{LN}<<\mathrm{HN})$ & $p=0.007(\mathrm{LF}<<\mathrm{HF})$ & - \\
\hline Jaera spp. abundance & - & $p=0.028(\mathrm{LF}>\mathrm{HF})$ & - \\
\hline Hyale nilssoni abundance & $p=0.029(\mathrm{LN}<\mathrm{HN})$ & - & - \\
\hline Littorina littorea abundance & $p=0.018(\mathrm{LN}<\mathrm{HN})$ & - & - \\
\hline \multirow[t]{2}{*}{ Lacuna spp. abundance } & $p=0.024(\mathrm{LN}<\mathrm{HN})$ & - & - \\
\hline & - & - & - \\
\hline \multicolumn{4}{|l|}{ Outlet macrofauna } \\
\hline Total abundance day & - & - & $p=0.008$ (SNK tests) \\
\hline Calliopiidae abundance night & $p=0.004(\mathrm{LN}>>\mathrm{HN})$ & - & - \\
\hline \multicolumn{4}{|l|}{ Zostera marina trays } \\
\hline Zostera marina shoots & $p=0.004 \mathrm{LN}>>\mathrm{HN})$ & $p=0.042(\mathrm{LF}<\mathrm{HF})$ & - \\
\hline \multicolumn{4}{|l|}{ Mesocosm metabolism } \\
\hline Carbon production day & $p=0.023(\mathrm{LN}>\mathrm{HN})$ & - & - \\
\hline
\end{tabular}

Differences in species composition were tested for by two-way PERMANOVA. All other differences were tested for by two-way ANOVA $L N$ low nutrient levels, $H N$ high nutrient levels, $L F$ low fish levels, $H F$ high fish levels

There were no significant effects for the main factor Fish and no $N \times F$ interaction effects. In the PCO from July, the cover of Ulva intestinalis and Ulva lactuca correlated positively with high nutrient levels and the cover of $F$. serratus correlated positively with low nutrient levels (Fig. 3a). In the PCO from October, the cover of U. lactuca, Spongomorpha aeruginosa and Cyanobacteria correlated positively with high nutrient levels and the cover of $F$. serratus and Polysiphonia fucoides correlated positively with low nutrient levels (Fig. 3b).

With regard to multivariate analyses of macrofauna cover on the steps, the responses in species composition were more modest than those for macroalgae as also may be seen in the PCO ordinations (Fig. 4a, b). In July, there were no significant effects of any of the treatment factors (Fig. 4a, Table 1), while in October, there was a weak significant effect of the factor Nutrients (Two-way PERMANOVA Pseudo- $F_{1,8}=2.47, p=0.036^{*}$, Table 2). At this latter stage for macrofauna species composition, Littorina littorea juveniles and both juveniles and adults of Mytilus edulis correlated positively with high nutrient levels and Electra pilosa correlated positively with low nutrient levels (Fig. 4b).

Looking at univariate variables for organism cover on the steps, in addition to the results already reported above 


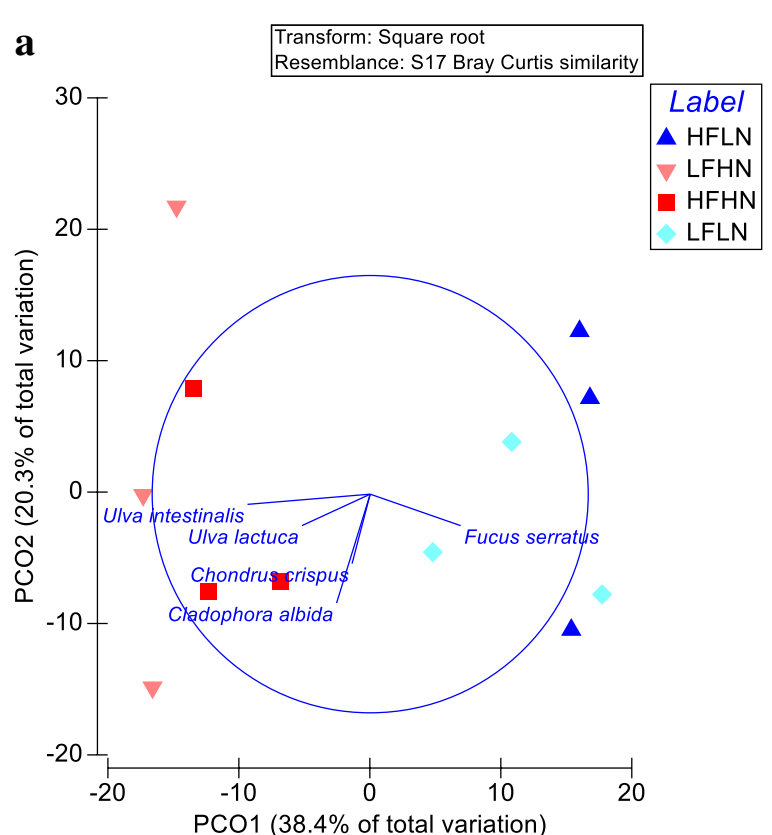

Fig. 3 PCO ordination describing macroalgal community composition in the twelve mesocosms with the species contributing the most (the correlation coefficient $>0.30$ ) as vector overlays in a July (after 3 months of experimentation), b October (after 6 months of experimen-

for cover of Fucaceans, cover of filamentous algae grouped into three classes and total cover of organims, the majority of the significant results was due to the factor Nutrients and there were very few significant main effects of Fish and interaction effects $N \times F$. In July, Margalef species richness and the cover of Fucus juveniles were both higher at low nutrient levels, while the cover of $U$. intestinalis, $U$. lactuca and Porphyra umbilicalis were all higher at high nutrient levels (Table 1). In July, there was further a significant $N \times F$ interaction for the barnacle Balanus improvisus $\left(F_{1,8}=8.89\right.$, $p=0.018 *)$. A posteriori SNK tests revealed that this interaction was due to more barnacles at low nutrient levels in the absence of mesopredatory fish and no differences between nutrient levels in the presence of fish (Table 1). In October, the cover of Fucus juveniles, P. umbilicalis, P. fucoides, Ceramium strictum as well as E. pilosa were all higher at low nutrient levels, whereas the cover of $U$. intestinalis, $U$. lactuca, S. aeruginosa and the number of L. littorea were all higher at high nutrient levels (Table 2). In October, there was also a significant $N \times F$ interaction for the cover of $U$. intestinalis $\left(F_{1,8}=6.74, p=0.032\right)$. A posteriori SNK tests revealed that this interaction was due to more $U$. intestinalis at high nutrient levels in the absence of mesopredatory fish and no differences between nutrient levels in the presence of fish (Table 2).

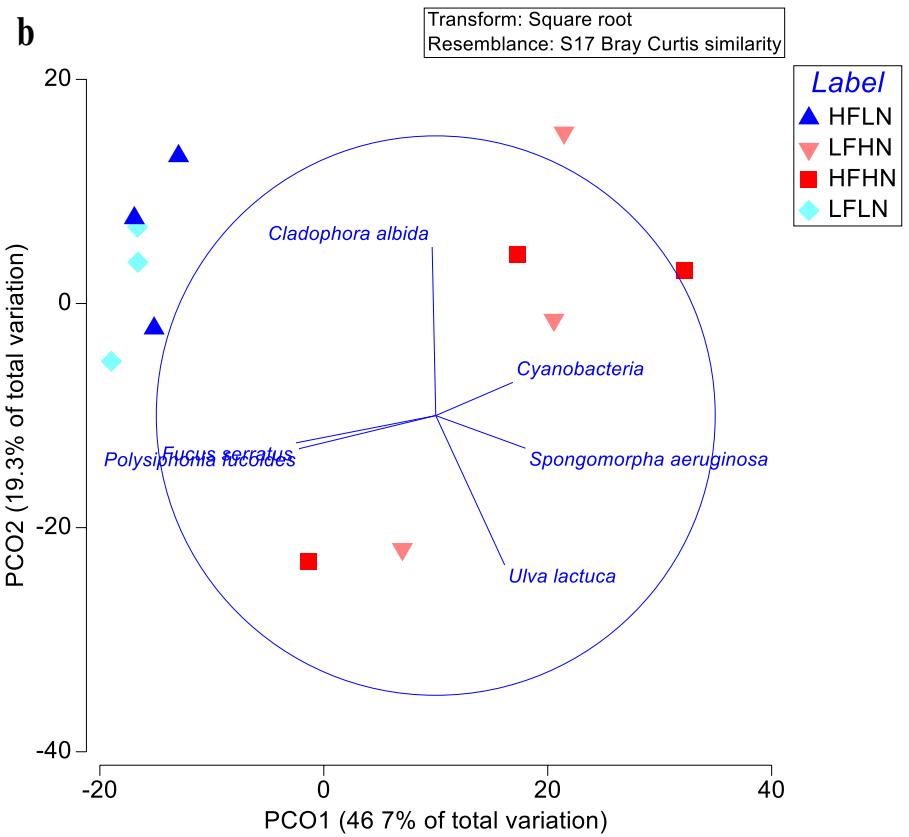

tation), the partly overlapping species labelling shows the position of vectors for Fucus serratus and Polysiphonia fucoides; $H$ high, $L$ low, $F$ fish, $N$ nutrients

\section{Mobile macrofauna as sampled by artificial substrates and from mesocosm outlet nets}

Multivariate PCO ordinations on macrofauna abundance data (square-root transformed) from eight pooled artificial substrates, four from one intertidal and four from one subtidal step, from each mesocosm showed distinct differences in species composition. In July, there were significant differences due to both nutrient enrichment and to mesopredatory fish (Table 1, Fig. 5a), but in October, there were only differences between nutrient enrichment levels (Table 2, Fig. 5b). In July, the abundance of Idotea spp., Hyale nilssoni and Lacuna spp. correlated positively with high nutrient levels, whereas Gammarus spp. correlated positively with mesopredatory fish (Table 1, Fig. 5a). The total abundance of mobile macrofauna was also higher in the presence of fish. In October, Shannon-Wiener diversity was higher in nutrient-enriched mesocosms and in mesocosms with mesopredatory fish. H. nilssoni, L. littorea and Lacuna spp. correlated positively with high nutrient levels, whereas Jaera albifrons correlated negatively with the presence of mesopredatory fish (Table 2, Fig. 5b).

Multivariate $\mathrm{PCO}$ ordinations on species abundance data (square-root transformed) of mobile macrofauna from mesocosm outlets showed significant differences between different treatments only in samples taken day time in July, but not in night samples from July and not in any samples from 
Fig. 4 PCO ordination describing macrofauna community composition in the twelve mesocosms with the species contributing the most (the correlation coefficient $>0.30$ ) as vector overlays in a July (after 3 months of experimentation), b October (after 6 months of experimentation); $H$ high, $L$ low, $F$ fish, $N$ nutrients

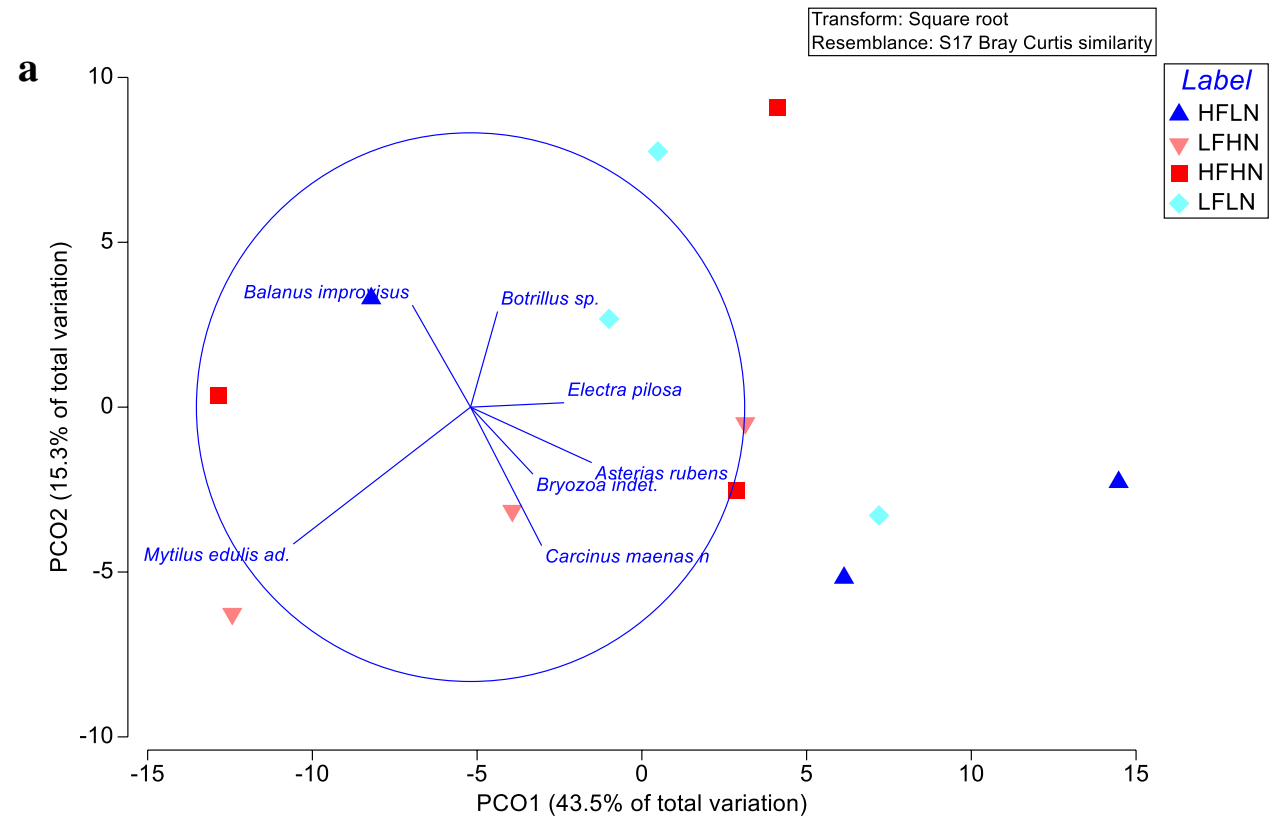

b

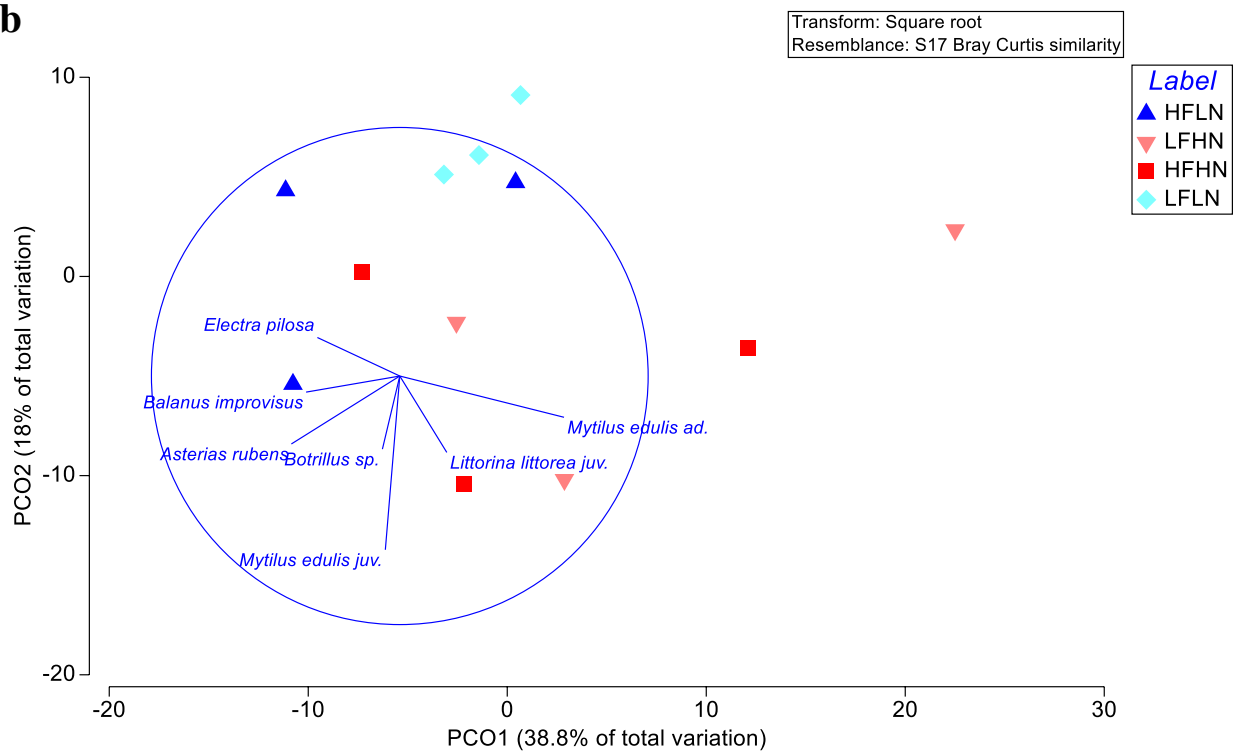

October (the latter data not shown). In the day samples from outlets in July, the abundance of Lacuna spp. and undetermined amphipods correlated negatively with the presence of fish (Table 1, Fig. 5c).

With regard to univariate analyses of outlet samples in July, total abundance of macrofauna and amphipods during both day and night and for Lacuna spp. during day time, there were significant main effects of Fish with all results demonstrating more individuals in the absence of mesopredatory fish (Table 1). In October, total abundance of outlet fauna presented a significant interaction during daytime and SNK tests revealed that this was due to higher abundance of macrofauna at low nutrient levels in the absence of mesopredatory fish and no differences in macrofauna abundance in the presence of mesopredatory fish (Table 2). In October, amphipods belonging to the family Calliopiidae were also significantly more abundant in outlet samples from low nutrient mesocosms (Table 2).

\section{Mesocosm production (function)}

Results from two-way ANOVAs on differences in mesocosm metabolism as $\mathrm{g} C$ produced or respired per hour are also presented in Tables 1 and 2. In July, both production $\left(F_{1,8}=6.73, p=0.032 *\right)$ and respiration $\left(F_{1,8}=73.82\right.$, $p<0.001 * * *)$ were significantly higher in high nutrient mesocosms. In October, however, the production was significantly higher in low nutrient mesocosms $\left(F_{1,8}=7.81\right.$, 
Fig. 5 PCO ordination describing macrofauna community composition in the twelve mesocosms with the species contributing the most (the correlation coefficient $>0.20$ ) as vector overlays in a artificial substrates on pooled intertidal and subtidal steps in July after 3 months of experimentation, b artificial substrates on pooled intertidal and subtidal steps in October after 6 months of experimentation, $\mathbf{c}$ samples from outlet pipes during day time in July; $H$ high, $L$ low, $F$ fish, $N$ nutrients

\section{a}

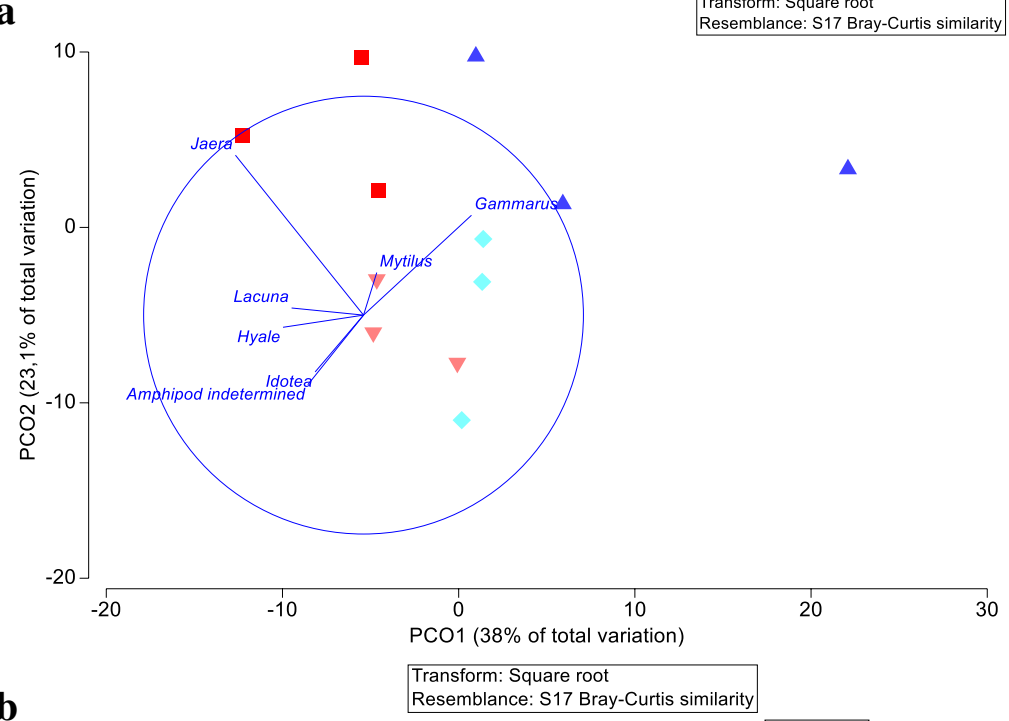

b

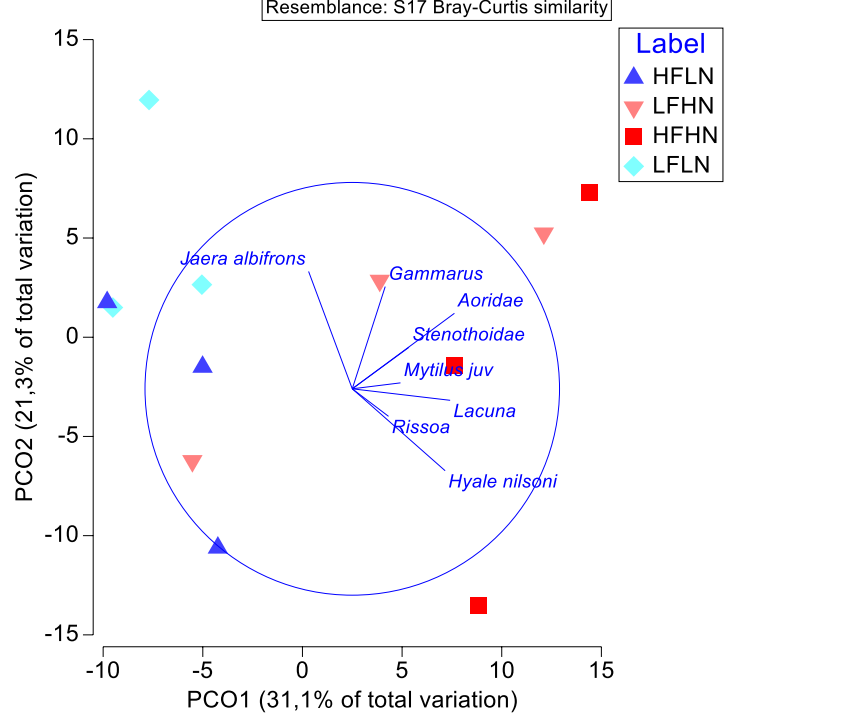

c

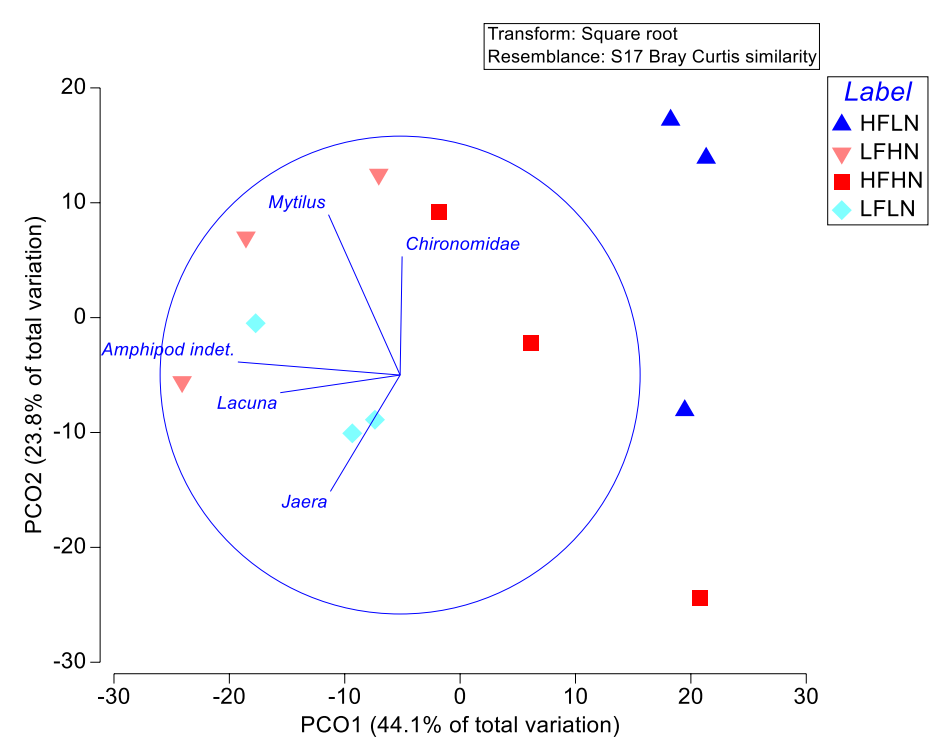


$p=0.023 *)$. There were no effects of Fish and no $N \times F$ interaction for carbon production and respiration at either time.

\section{Number of individuals of eelgrass, Zostera marina}

Results from two-way ANOVAs on the number of Z. marina shoots counted in October, at the termination of the experiment, are included in Table 2 . This number was significantly higher at low nutrient levels $\left(F_{1,8}=15.45, p=0.004 * *\right)$ and also in the presence of mesopredatory fish $\left(F_{1,8}=5.88\right.$, $p=0.042 *)$.

\section{Analyses of the number and size of mesopredatory fish as well as fish stomach content}

The counting of mesopredatory fish individuals at the end of the study, when the basins were emptied, showed that the targeted number of 30 fish individuals per basin for each fish treatment roughly prevailed (range 23-37 individuals) throughout the experiment (Table 3). Total length of the wrasses ranged mainly between 10 and $17 \mathrm{~cm}$ (the range in average fish size among mesocosms was $11.5-12.6 \mathrm{~cm}$ ). The presence of a few small individuals indicated that some individuals had entered the mesocosms through the incoming water. This also explains why a few small fish individuals were found in two non-fish mesocosms. This happened in one high nutrient mesocosm and in one low nutrient mesocosm (4 and 13 small fish individuals, respectively).

Judging from samples of stomach content taken in October, in connection with the closing of the experiment, the major food items of the fish consisted of small blue mussels, amphipods and gastropods. The species/taxa found in the stomachs of 187 goldsinny wrasses were as follows: 450 small individuals of M. edulis, 261 amphipods (small individuals of different species, some large Gammarus spp.), 113 gastropods (mainly small Littorina and Rissoa), $53 \mathrm{~B}$. improvisus and 19 Nereis pelagica. In addition, a few isopods, a few small fish (probably gobids) and insect larvae were also found. Note that the stomach content is only representative for consumed food items during the closing day in October. Unfortunately, data of fish diets are lacking for July, when the consumption by fish assumingly exerts a bigger impact on the mesocosm communities (compare Table 1 with Table 2).

\section{Discussion}

This controlled mesocosm study mainly revealed typical eutrophication responses, while the responses to the mesopredatory fish release were much more modest. Nutrient enrichment led to more green ephemeral macroalgae and less perennial Fucacean and filamentous brown and red macroalgae (Fig. 2). Also certain grazing animal groups, such as several species of gastropods and the amphipod $H$. nilssoni, were numerically stimulated at high nutrient levels. Simultaneously, the effects on macroalgal and macrofaunal diversity and community function were weak, much weaker than previously reported (e.g. Kraufvelin et al. 2010). The significant responses to the addition of mesopredatory fish and also to the addition of fish and nutrients in combination were clearly fewer than the responses to nutrient addition alone in July and almost non-existent in October (Tables 1, 2). Fish predation reduced the numbers of some mesograzers, although this did not seem to have very evident effects on the structure of the macroalgal community. Instead the fish probably consumed a lot of juvenile Mytilus in the mesocosms, a filter feeding species not grazing on algal turfs, but potentially competing for space with both perennial and annual macroalgae (O'Connor et al. 2006, Erlandsson et al. 2011). A reduced grazing of ephemeral algae due to the addition of mesopredatory fish with potential negative effects of the macrophyte canopy, which was expected based on results from previous studies (e.g. Moksnes et al. 2008; Eriksson et al. 2009; Baden et al. 2012; Donadi et al. 2017) and meta-analyses (Östman et al. 2016), was thus not very evident in this mesocosm experiment. On the contrary, it even seemed that the presence of mesopredatory fish on the whole had more positive than negative impact on the macrophyte community structure of the mesocosms, e.g. for the foundation species $F$. serratus and Z. marina. Although this lack of clear-cut responses to the mesopredatory fish partly opposes the ones previously reported, it is to some extent supported by observations from field studies by Bergström et al. (2016) and Kraufvelin et al. (2017) on the Swedish west coast, where wrasses were more common in the structurally most complex habitats with the densest cover of perennial macrophytes. The lack of clear negative responses to mesopredator release among macrophytes is also important from a management perspective as it may have implications

Table 3 Number of fish (Ctenolabrus rupestris) and average total length $( \pm \mathrm{SE})$ in the mesocosms in October (originating from 30 added fish individuals to each of these mesocosms in May and a refill of 15 more individuals in late July)

\begin{tabular}{lllllll}
\hline Treatment & HFLN1 & HFHN2 & HFLN3 & HFHN1 & HFLN2 & HFHN3 \\
\hline Number of fish & 37 & 23 & 33 & 28 & 33 \\
Average length $(\mathrm{cm})$ & $11.9(0.4)$ & $12.6(0.2)$ & $12.2(0.3)$ & $11.9(0.4)$ & $11.5(0.4)$ & $11.8(0.3)$ \\
\hline
\end{tabular}


for the ongoing wrasse fishery in Swedish and Norwegian waters (Skiftesvik et al. 2014; Halvorsen et al. 2017; Olsen et al. 2018). Based on the findings in this study, when comparing low fish treatments in comparison to high fish treatments, especially in the presence of high nutrient loads, it would suggest that a more intense wrasse fishery may lower the cover of perennial macrophytes and shift the shore ecosystems into systems dominated by ephemeral green algae. As such, this suggests that the wrasse fishery should probably be subjected to some regulation with the consideration of no-take areas to minimise potential impacts.

\section{Responses to nutrient enrichment in the macrophyte and macrofauna assemblages}

Evident similarities in responses in this mesocosm study with other studies focusing on nutrient enrichment in temperate macroalgal communities can be seen in the multivariate PCO ordinations, where the twelve mesocosms clearly group on the basis of nutrient enrichment level in both June (Fig. 3a) and in October (Fig. 3b). This pattern can also be seen from the results for the two-way ANOVAs on dominant macrophyte species (Tables 1,2 ) and for the temporal development of dominating species (Fig. 2). Similar results have been obtained previously in these mesocosms (Bokn et al. 2003; Karez et al. 2004; Kraufvelin et al. 2006b, 2010; Kraufvelin 2007). The increased dominance of ephemeral algae above perennial macroalgae due to nutrient enrichment, typically seen on temperate rocky shores (Valiela et al. 1997; Cloern 2001; Worm and Lotze 2006), is basically linked to ecophysiological traits (growth rate, nutrient requirements and uptake rates), where thinner algae are favoured above thicker algae under eutrophicated conditions (Wallentinus 1984; Pedersen and Borum 1996). The stimulation of annual fast-growing macroalgae often accentuates the competition for light and space and may retard perennial species, harm their recruitment or growth and decrease their cover (Cloern 2001; Råberg et al. 2005; Kraufvelin et al. 2006b, 2007; Wahl et al. 2011). The results for Z. marina, in the trays on the mesocosm floor that show a much lower amount of living shoots in nutrient enriched mesocosms may well be due to competition with ephemeral algae, but the short experimental period and visible shoot damages hints that some grazing macroinvertebrate species that were overconsuming eelgrass blades probably played a bigger role.

Many of the significant responses to nutrient enrichment that were observed within the mesocosm macrofauna in this study have also previously been reported from Solbergstrand mesocosms and from field studies of temperate rocky shore communities, whereas other results are more novel. It is known, for instance, that the macrofauna community shows weaker responses to nutrient enrichment than the macroalgal community (Kraufvelin et al. 2002; 2006a, 2010; b; Bokn et al. 2003) and this study is no exception (compare, e.g. the PCO ordinations in Figs. 3 and 4 as well as the corresponding PERMANOVAs with each other). The stimulation of L. littorea and Gammarus spp. by high nutrient levels have been observed before (Kraufvelin et al. 2002, 2006a; Díaz et al. 2012), while the stimulated abundance of $H$. nilssoni, Lacuna spp. and Rissoa spp. are more novel findings. The stimulated gastropod abundances found in this study deviate from the meta-analysis by Östman et al. (2016) where only the abundance of amphipods/isopods were stimulated by nutrient enrichment, but not total abundance of gastropods. These latter differences can probably be explained by the longer duration of these mesocosm experiments compared to most studies examined for the meta-analysis.

For community function, registered as total mesocosm production and respiration by the $\mathrm{pH}-\mathrm{CO}_{2}$ method, only the higher respiration in high nutrient mesocosms in July is in agreement with previous findings from these mesocosms (Kraufvelin et al. 2010), not the higher production in high nutrient mesocosms in July and in low nutrient mesocosms in October. The macroalgal beds in this study are, however, younger $(0.25-2.5$ years old) and thinner than the ones studied in Kraufvelin et al. (2010) that were 2.5-5 years old and considerably denser and which also by that time had been exposed much longer to nutrient enrichment which ultimately thinned out the macroalgal canopies. Thus the function of the latter communities, whose production decreased significantly due to nutrient enrichment, was probably affected more negatively by nutrient addition than the ones of this study. Correspondingly, Eriksson et al. (2006) reported the role of a dense canopy cover for preventing a significant increase in net biomass production from nutrient enrichment. Small effects of nutrient enrichment on thick macroalgal canopies have previously also been reported by Bokn et al. (2003) and Russell and Connell (2005).

\section{Responses to mesopredatory fish and the $N \times F$ interaction in macrophyte and macrofauna assemblages}

Addition of mesopredatory fish, both seen as the main effect of Fish and also as the interaction factor $N \times F$, presents much fewer significant responses than nutrient addition alone in July and by October, there are hardly any significant responses at all (Tables 1,2). The lack of significant responses to Fish and to $N \times F$ within the mesocosm macrophyte communities is noteworthy in the light of the clear responses reported in the existing literature. Significant main responses in macrophyte cover to factor Fish are only found for $F$. serratus cover in July (Table 1) and for the number of $Z$. marina shoots in October (Table 2), which both are significantly higher in the presence of mesopredatory fish. Apparently, the feeding activity of the mesopredatory 
fish reduced the numbers of certain grazers and may have played a favourable role for these important canopy-forming macrophytes.

Significant responses to the main factor Fish and to the $N x F$ interaction were found for mobile macrofauna mainly in July. Differences in species composition and lower abundances of both amphipods and Lacuna spp. in outlet samples in the presence of fish are also examples of such results. In July, there are in addition a couple of significant $N \times F$ interactions (Table 1), e.g. for the cover of B. improvisus and for the abundance of Lacuna spp. that suggest that the mesopredatory fish indeed do exert macrofauna community control during the summer season. In October, only a few significant main effects with the factor Fish involved are visible and these are fewer Jaera spp. on mesocosm steps in the presence of fish and a significant $N \times F$ interaction for the total abundance of macrofauna in outlet samples. The differing results between seasons can be explained by a decrease in pressure from the goldsinny wrasse from summer to autumn with lower temperatures and shorter day length as temperatures have strong influence on animal metabolic processes and consumption rates (Deady et al. 1995; Doney et al. 2012). In a general context, it must also be noted here that the significant changes in macrofauna species that are observed due to the presence of mesopredatory fish are apparently not strong enough to exert evident top-down control on the macroalgae.

\section{Possible reasons for the weak community responses to the top-down mesopredator release}

The general lack of clear-cut effects on macroalgal communities via altered mesograzer assemblages due to the addition of mesopredatory fish, at least compared to the responses to nutrient enrichment and to effects reported in the literature, may have several explanations, or rather, it may be due to a combination of many different factors. Among these, there may be: (1) compensatory mechanisms within the system, (2) disparity in the impact of grazers, (3) issues related to the mesopredators, (4) temporal issues with the study, (5) issues with mesocosm realism and (6) that the top-down mesopredator impacts on macroalgal communities are not very strong after all, at least not compared to bottom-up impacts. Some of these factors are illustrated in Fig. 6 and represent a diversity of interaction pathways that clearly differ from the assumptions illustrated in Fig. 1. Thus, the

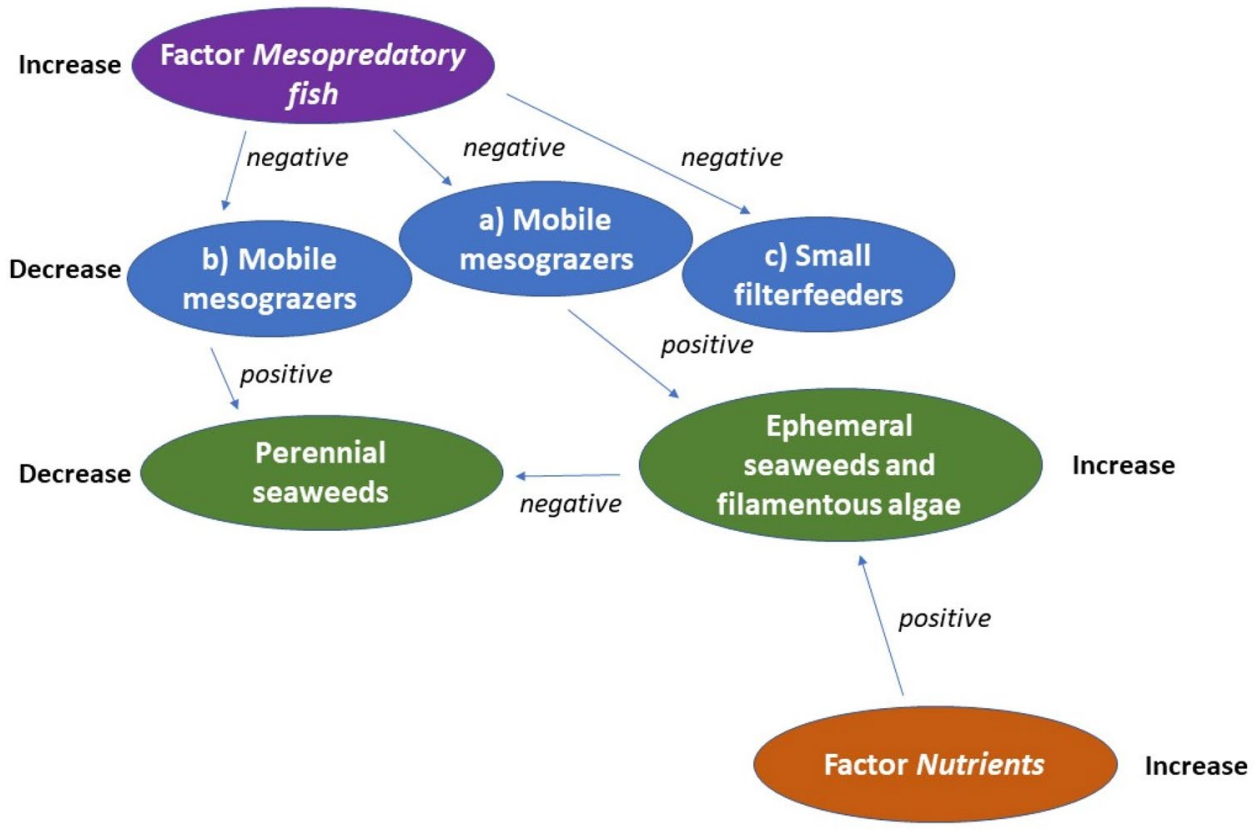

Fig. 6 Conceptual model of the central top-down and bottom-up pathways as a modification of Fig. 1 based on the results from this study. When nutrients increase (in connection with eutrophication), ephemeral algae are favoured with effects on the algal compartments of the model. Reduced densities of top predators (not shown in the figure) will favour (release) the smaller mesopredatory fish that will affect the macroinvertebrates negatively, but in this study this does not lead to strong negative responses on perennial seaweeds. This may be due to varying responses among different macroinvertebrate groups to the fish predation, where: a indicates the expected pathway from mesopredators to mesograzers from the literature that also is the one presented in Fig. 1, b shows fish predation on other macroinvertebrate species that are grazing directly on the perennial seaweeds and their reduction affects the seaweeds positively and $\mathbf{c}$ shows fish predation on small filter feeders (mussels) that seem to release other macroinvertebrate species from predation. The favouring of ephemeral algae from nutrients will, however, still contribute to overgrowth of and a decrease in perennial algae, and bottom-up nutrient enrichment is thus a much stronger driver than top-down release of mesopredatory fish in this study 
factors that potentially are involved are also elucidated in more detail below.

1. Compensatory mechanisms within the mesocosm communities could be one reason for the weak response to the mesopredator release, i.e. that the major macroinvertebrate prey species may not have been the most efficient grazers of ephemeral algae and that the mesopredatory fish was a generalist consuming the most easily accessible prey. Previously, a high number of common macrofauna species have been identified in these mesocosms (Kraufvelin et al. 2002), and also this study showed more than 20 common species on mesocosm steps, in macroalgae, from mesocosm outlets and in fish stomachs. Duffy et al. (2015) state that reduction of mesograzers could enhance eutrophication effects, but apparently, a high diversity of mesograzers could also modulate these effects. In another study, Duffy et al. (2013) report that "functional redundancy" increases the community resistance to stressors, and among the high number of herbivore species in our experiment, other species may likely step in and fill the grazing function, if some species are numerically reduced due to predation. This could not be seen directly in our results for mobile macrofauna, but stomach analyses reveal that small individuals of $M$. edulis were the most abundant prey organisms at the end of the experiment in October and also quite many $B$. improvisus were consumed, but the latter barnacle species to a smaller extent. This indicates that sessile and filter feeding organisms not grazing on the macroalgae may be easily found and caught by the fish and serve as common preys throughout the experimental period and thereby relieve the predator pressure on mobile grazers that were more capable of affecting macroalgal community structure. In the field, small individuals of Mytilus rather decrease in numbers throughout summer in seaweed communities (Christie et al. 2003), and may function as substitute prey items for the fish in a similar way. In the mesocosms, however, blue mussels find a refuge from sea stars and shore crabs on the wave machines and may thus become abundant enough to serve as substitute food for the fish.

2. Disparity in the impact of mesograzers, e.g. that some species are mainly grazing on epiphytes while other species may be grazing on perennial macroalgae, could be another reason for the weak macroalgal community response to the mesopredatory release. If the mesograzers mainly reduce fast-growing ephemeral algae, as described by the "mutualistic mesograzer model" (Duffy et al. 2013), and these mesograzers are consumed by the mesopredators, negative effects may be expected on perennial macrophytes. However, the mesopredators may also impose positive effects on perennial macrophytes by reducing densities of mesograzers feeding on (e.g. some gastropods, in this study potentially both Lacuna spp. and Rissoa spp.) or fouling (e.g. some tube-building amphipods) the perennial macrophytes (Fredriksen et al. 2004; Lewis and Anderson 2012) or by direct mesopredator consumption of ephemeral algae (Heck et al. 2000, but not found in stomachs here). Therefore, functional diversity and trophic interactions may have great influence on the strength and direction of trophic cascades (Duffy et al. 2015; Östman et al. 2016).

3. The identity, foraging efficiency and density of the mesopredator, e.g. which fish species that is studied, or if shore crabs or even shrimps could be more efficient mesopredators, as well as determination of the realistic density of the mesopredator, are all factors that may affect the response strength of mesopredator releases in the field. The density of goldsinny wrasse was in this experiment ca 2.5-4 fish per $\mathrm{m}^{3}$ of water at high and low tide, respectively. Moy et al. (2007) got more than 50 wrasses in $20 \mathrm{~m}$ long gillnets with fine mesh size in kelp and seaweed beds in southern Norway and from the Swedish part of Skagerrak, Bergström et al. (2016) and Kraufvelin et al. (2017) report 7-15 goldsinny wrasses per fyke net and night. These results together with the data from Halvorsen et al. (2017) and the beach seine data from Gjøsæter and Paulsen (2004) give, however, insufficient background for a determination of realistic densities per $\mathrm{m}^{2}$, although the applied numbers in the present experiment may be defended with the abovementioned recordings and own personal observation of densities from shore areas close to the Solbergstrand mesocosm facility. With regard to the efficiency of the mesopredator, a number of other mesopredator species may be present at the same time in natural seaweed communities, and deserve to be studied in more detail in renewed experiments.

4. Temporal issues with the study such as the significance of the length of the experiment and the sufficiency of time for responses to occur, the maturation and resilience of the studied communities and the possible role of seasonality are also important factors that may have played their part for differing responses to the mesopredator release in this experiment in comparison to field studies. As this study only took place during one growth season (6 months), there may not be time for full-scale responses to occur, but such responses could maybe take place if longer studies were conducted. On the other hand, these mesocosm experiments were longer than the ones investigated in the meta-analysis by Östman et al. (2016) so this study should suffer less from potential inaccuracies related to the length of the experiment. Still, gastropod mesograzers develop slower and have clearly longer generation times (usually 
6-12 months) than crustacean mesograzers (Eriksson et al. 2011; Duffy et al. 2015). This means that longer time scales may be needed for responses to occur in many mesograzers and to become visible in the macrophytes due to grazing activities. Seasonal differences among studies, such as a normal die-off of some macroalgal species (mainly ephemeral ones) during autumn may also play their parts (Kraufvelin 2007; Kraufvelin et al. 2010). This is also true for lower consumption rates among mesopredators during the autumn than during the summer (Deady et al. 1995; Doney et al. 2012).

5. The fact that this study was conducted in mesocosms that never are completely realistic and equal to the real world may be another reason for the weak responses to mesopredator release. The realism of mesocosm studies can always be questioned and need to be discussed and pin-pointed when evaluating the results of such experiments. This has previously been done by for example Perez (1995) and Kraufvelin (1999) regarding mesocosms in general and also thoroughly for the Solbergstrand mesocosms in previous studies, more specifically the ones by Kraufvelin et al. (2006b, 2010) and Díaz et al. (2012). Still, with regard to this particular study, a number of undisputable advantages with using the mesocosm approach are also present, at least compared to the alternative of visiting many different field sites and establishing controlled treatments in situ. Among these, there are controlled, constant differences in nutrient treatment levels and in levels of mesopredatory fish (the treatment factors) throughout the experimental facility. There are also equal substrate material, topography, wave action (both wave height and direction), water currents, water temperatures, salinity and light conditions (both intensity and timing). The mesocosm facility further includes a restricted accessibility by humans, mammals and birds. Most importantly for this study, there are three replicated "shores" of each treatment combination available within a few metres from each other and these shores/mesocosms can be accessed/sampled by the same researchers within minutes to hours. This enables a repeated "simultaneous" sampling, e.g. with regard to external and internal physical and biological conditions, that never will be possible to achieve in the field.

6. The possibility that there are not very strong top-down mesopredator influences on these macroalgal communities, at least not in comparison to the bottom-up influences by nutrient enrichment, should also be considered as an alternative when examining possible reasons for the weak responses to the mesopredator release in this study. The meta-analysis by Östman et al. (2016), for instance, found no interactive effects of bottom-up and top-down manipulations of Fucus and Zostera and the mesopredators themselves had non-significant effects on seagrass/seaweed. Similar results are indeed seen in this mesocosm study, although the possible explanations for the observed patterns are multifaceted and difficult to settle with very strong certainties.

\section{Concluding remarks}

This is the first controlled study of single and interactive effects on rocky shore communities by nutrient enrichment and mesopredatory fish release at the mesocosm scale revealing many strong responses to nutrient enrichment, but clearly fewer and weaker responses to the mesopredator release. Nutrient enrichment leads to more ephemeral green algae and less ephemeral and perennial brown and red macroalgae and it also leads to a numerical stimulation of both crustacean and gastropod mesograzers and this study is corroborating previous studies conducted in these mesocosms (see e.g. Kraufvelin et al. 2010 or Díaz et al. 2012) while at the same time demonstrating a high degree of repeatability (Kraufvelin 1999). Addition of mesopredatory fish and also addition of fish and nutrients in combination reduce the abundance of some mesograzer species, but hardly to such an extent that negative cascading effects occur all the way down to the macroalgal assemblages. The latter observation was partly an unexpected result judging from existing literature. From this experiment, it may thus be concluded that many factors, conditions and processes take part in the expression and moderation of top-down and bottomup effects on rocky shores and that the response patterns and their mechanisms are therefore not easily disentangled. Complex systems with high diversities over many different functional groups like the communities in these mesocosms may have high resilience (resistance) to pressures such as increase in intermediate predation and decreased grazing. This may partly explain the specific results achieved such as why the top-down effects were diluted in this mesocosm study and why the mesocosm communities seems to be capable to resist a stressor, whereas the same stressor elsewhere (e.g. in the field) even may lead to regime shifts. Therefore, it is challenging to generalise models of food web interactions across areas on the basis of these results and there are still evident needs to improve our understanding of factors (and predator densities) regulating top-down and bottom-up processes in rocky shore ecosystems (Worm et al. 2000; Masterson et al. 2008; Bulleri et al. 2012; Östman et al. 2016). Still, an attempt has been made to refine our original conceptual model of top-down and bottom-up events in Fig. 1 based on the results from this study (see Fig. 6).

For management, it can be advised that efforts of both nutrient reduction and for the strengthening of piscivorous 
fish populations are continued as both these measures, in addition to healthier environments, should also serve towards an improved status of macrophytic foundation communities (Östman et al. 2016; Kraufvelin et al. 2018). On the basis of the results from this study, possible measures targeting the reduction of mesopredatory wrasse populations should, however, be used with caution and not be applied over large scales before more thorough testing. An intensified labrid fishery is already taking place in coastal waters of southern Norway and western Sweden and presents additional challenges for management and joint reasons for conducting more studies within this topic (Halvorsen et al. 2017; Olsen et al. 2018). If the presence of certain levels of mesopredatory fish actually is beneficial for the community structure of shallow water macrophytes, as the present study indicates for the habitat-forming species $F$. serratus and $Z$. marina, a too heavy reduction of mesopredatory fish may have its own dramatic and this far neglected and unforeseen ecosystem implications.

Acknowledgements Open access funding provided by Swedish University of Agricultural Sciences. We are grateful to Per-Ivar Johannessen and Oddbjørn Pettersen for excellent daily maintenance of the Solbergstrand mesocosms and to Marius, Lucinda and Nicodemus Kraufvelin for field assistance including fishing of additional goldsinny wrasse individuals for the mesocosm refill in late July 2012. The comments from two reviewers and the editor greatly improved the final product.

Funding The main part of this work was funded by internal money from the Norwegian Institute for Water Research (NIVA). Patrik Kraufvelin also received financial support from Svenska Litteratursällskapet i Finland r.f. (Ingrid, Margit och Henrik Höijers Donationsfond II) and internal "paper writing" money from the Department of Aquatic Resources, Institute of Coastal Research, Swedish University of Agricultural Sciences.

Data availability The datasets analysed during the current study are available from the corresponding author on reasonable request.

Conflict of interest All authors declare that they have no conflict of interest.

Ethical approval All applicable international, national (Norwegian Food Safety Authorities) and institutional guidelines for the care and use of animals were followed.

Open Access This article is licensed under a Creative Commons Attribution 4.0 International License, which permits use, sharing, adaptation, distribution and reproduction in any medium or format, as long as you give appropriate credit to the original author(s) and the source, provide a link to the Creative Commons licence, and indicate if changes were made. The images or other third party material in this article are included in the article's Creative Commons licence, unless indicated otherwise in a credit line to the material. If material is not included in the article's Creative Commons licence and your intended use is not permitted by statutory regulation or exceeds the permitted use, you will need to obtain permission directly from the copyright holder. To view a copy of this licence, visit http://creativecommons.org/licenses/by/4.0/.

\section{References}

Almgren T, Dyrssen D, Strandberg M (1975) Determination of pH on the moles per kg seawater scale (Mw). Deep-Sea Res 22:635-646. https://doi.org/10.1016/0011-7471(75)90051-0

Anderson MJ (2005) Permutational multivariate analysis of variance. University of Auckland, Auckland, Department of Statistics

Anderson MJ, Gorley RN, Clarke RK (2008) PERMANOVA + for PRIMER: guide to software and statistical methods. PRIMER-E, Plymouth

Andersson L (1996) Trends in nutrients and oxygen concentrations in the Skagerrak-Kattegat. J Sea Res 35:63-71. https://doi. org/10.1016/S1385-1101(96)90735-2

Araújo RM, Assis J, Aguillar R, Airoldi L, Bárbara I, Bartsch I, Bekkby T, Christie H, Davoult D, Derrien-Courtel S, Fernandez C, Fredriksen S, Gevaert F, Gundersen H, Le Gal A, Lévêque L, Mieszkowska N, Norderhaug KM, Oliveira P, Puente A, Rico JM, Rinde E, Schubert H, Strain EM, Valero M, Viard F, Sousa-Pinto I (2016) Status, trends and drivers of kelp forests in Europe: an expert assessment. Biodivers Conserv 25:1319-1348. https://doi. org/10.1007/s10531-016-1141-7

Baden S, Gullström M, Lunden B, Pihl L, Rosenberg R (2003) Vanishing seagrass (Zostera marina L.) in Swedish coastal waters. Ambio 32:374-377. https://doi.org/10.1579/0044-7447-32.5.374

Baden S, Emanuelsson A, Pihl L, Svensson CJ, Åberg P (2012) Shift in seagrass food web structure over decades is linked to overfishing. Mar Ecol Prog Ser 451:61-73. https://doi.org/10.3354/meps09585

Barrón C, Marbá N, Duarte CM, Pedersen MF, Lindblad C, Kersting K, Moy F, Bokn T (2003) High organic carbon export precludes eutrophication responses in experimental rocky shore communities. Ecosystems 6:144-153. https://doi.org/10.1007/s 1002 1-002-0402-3

Bergström L, Karlsson M, Bergström U, Pihl L, Kraufvelin P (2016) Distribution of mesopredatory fish determined by habitat variables in a predator-depleted coastal system. Mar Biol 163:201. https://doi.org/10.1007/s00227-016-2977-9

Bergström L, Karlsson M, Bergström U, Pihl L, Kraufvelin P (2019) Relative impacts of fishing and eutrophication on coastal fish assessed by comparing a no-take area with an environmental gradient. Ambio 48:565-579. https://doi.org/10.1007/s1328 0-018-1133-9

Bokn T, Lein TE (1978) Long-term changes in fucoid associations of inner Oslofjord, Norway. Norw J Bot 25:9-14

Bokn TL, Moy FE, Christie H, Engelbert S, Karez R, Kersting K, Kraufvelin P, Lindblad C, Marbá N, Pedersen MF, Sørensen K (2002) Are rocky shore ecosystems affected by nutrient enriched seawater? Some preliminary results from a mesocosm experiment. Hydrobiologia 484:167-175. https://doi.org/10.1023/A:10213 65307438

Bokn TL, Duarte CM, Pedersen MF, Marbá N, Moy FE, Barrón C, Bjerkeng B, Borum J, Christie H, Engelbert S, Fotel FL, Hoell EE, Karez R, Kersting K, Kraufvelin P, Lindblad C, Olsen M, Sanderud KA, Sommer U, Sørensen K (2003) The response of experimental rocky shore communities to nutrient additions. Ecosystems 6:577-594. https://doi.org/10.1007/s10021-002-0108-6

Britten GL, Dowd M, Minto C, Ferretti F, Boero F, Lotze HK (2014) Predator decline leads to decreased stability in a coastal fish community. Ecol Lett 17:1518-1525. https://doi.org/10.1111/ ele. 12354

Bulleri F, Russell BD, Connell SD (2012) Context-dependency in the effects of nutrient loading and consumers on the availability of space in marine rocky environments. PLoS One 7:e33825. https ://doi.org/10.1371/journal.pone.0033825

Chemello S, Vizzini S, Mazzola A (2018) Regime shifts and alternative stable states in intertidal rocky habitats: State of the art and new 
trends of research. Estuar Coast Shelf Sci 214:57-63. https://doi. org/10.1016/j.ecss.2018.09.013

Christie H, Kraufvelin P (2004) Mechanisms regulating amphipod population density within macroalgal communities with restricted predator impact. Sci Mar 68(Suppl 1):189-198. https://doi. org/10.3989/scimar.2004.68s1189

Christie H, Jørgensen NM, Norderhaug KM, Waage-Nielsen E (2003) Species distribution and habitat exploitation of fauna associated with kelp (Laminaria hyperborea) along the Norwegian coast. J Mar Biol Assoc UK 83:687-699. https://doi.org/10.1017/S0025 $315403007653 \mathrm{~h}$

Christie H, Norderhaug KM, Fredriksen S (2009) Macrophytes as habitat for fauna. Mar Ecol Prog Ser 396:221-233. https://doi. org/10.3354/meps08351

Clarke KR (1993) Non-parametric multivariate analyses of changes in community structure. Austral J Ecol 18:117-143. https://doi. org/10.1111/j.1442-9993.1993.tb00438.x

Clarke KR, Gorley RN (2006) PRIMER v.6: user manual/tutorial. PRIMER-E Ltd, Plymouth

Cloern JE (2001) Our evolving conceptual model of the coastal eutrophication problem. Mar Ecol Prog Ser 210:223-253. https ://doi.org/10.3354/meps210223

Daan N, Gislason H, Pope JG, Rice JC (2005) Changes in the North Sea fish community: evidence of indirect effects of fishing? ICES J Mar Sci 62:177-188. https://doi.org/10.1016/j.icesj ms.2004.08.020

Darwall WRT, Costello MJ, Donnelly R, Lysaght S (1992) Implication of life-history strategies for a new wrasse fishery. J Fish Biol 41:111-123. https://doi.org/10.1111/j.1095-8649.1992.tb03873.x

Deady S, Varian SJ, Fives JM (1995) The use of cleaner-fish to control sea lice on two Irish salmon (Salmo salar) farms with particular reference to wrasse behaviour in salmon cages. Aquaculture 131:73-90. https://doi.org/10.1016/0044-8486(94)00331-H

Díaz ER, Kraufvelin P, Erlandsson J (2012) Combining gut fluorescence technique and spatial analysis to determine Littorina littorea grazing dynamics in nutrient-enriched and nutrient-unenriched littoral mesocosms. Mar Biol 159:837-852. https://doi.org/10.1007/ s00227-011-1860-y

Donadi S, Austin ÅN, Bergström U, Eriksson BK, Hansen JP, Jacobson P, Sundblad G, van Regteren M, Eklöf JS (2017) A cross-scale trophic cascade from large predatory fish to algae in coastal ecosystems. Proc R Soc B 284:20170045. https://doi.org/10.1098/ rspb.2017.0045

Donadi S, Austin ÅN, Svartgren E, Eriksson BK, Hansen JP, Eklöf JS (2018) Density-dependent positive feedbacks buffer aquatic plants from interactive effects of eutrophication and predator loss. Ecology 99:2515-2524. https://doi.org/10.1002/ecy.2501

Doney SC, Ruckelshaus M, Duffy JE, Barry JP, Chan F, English CA, Galindo H, Grebmeier JM, Hollowed AB, Knowlton N, Polovina J, Rabalais NN, Sydeman WJ, Talley LD (2012) Climate change impacts on marine ecosystems. Ann Rev Mar Sci 4:11-37. https ://doi.org/10.1146/annurev-marine-041911-111611

Duffy JE, Hughes AR, Moksnes PO (2013) Ecology of seagrass communities. In: Bertness MD, Bruno JF, Silliman BR, Stachowicz JJ (eds) Marine community ecology and conservation. Sinauer Associates Inc, Sunderlands, Massachusetts, pp 271-297

Duffy JE, Reynolds PL, Boström C, Coyer JA, Cusson M, Donadi S, Douglass JG, Eklöf JS, Engelen AH, Eriksson BK, Fredriksen S, Gamfeldt L, Gustafsson C, Hoarau G, Hori M, Hovel K, Iken K, Lefcheck JS, Moksnes P-O, Nakaoka M, O’Connor MI, Olsen JL, Richardson JP, Ruesink JL, Sotka EE, Thormar J, Whalen MA, Stachowicz JJ (2015) Biodiversity mediates top-down control in eelgrass ecosystems: a global comparative-experimental approach. Ecol Lett 18:696-705. https://doi.org/10.1111/ ele. 12448
Eriksson BK, Johansson G, Snoeijs P (2002) Long-term changes in the macroalgal vegetation of the inner Gullmar fjord, Swedish Skagerrak coast. J Phycol 38:284-296. https://doi.org/10.104 6/j.1529-8817.2002.00170.x

Eriksson BK, Rubach A, Hillebrand H (2006) Biotic habitat complexity controls species diversity and nutrient effects on net biomass production. Ecology 87:246-254. https://doi.org/10.1890/05-0090

Eriksson BK, Ljunggren L, Sandström A, Johansson G, Mattila J, Rubach A, Råberg S, Snickars M (2009) Declines in predatory fish promote bloom-forming macroalgae. Ecol Appl 19:1975-1988. https://doi.org/10.1890/08-0964.1

Eriksson BK, van Sluis C, Sieben K, Kautsky L, Råberg S (2011) Omnivory and grazer functional composition moderate cascading trophic effects in experimental Fucus vesiculosus habitats. Mar Biol 158:747-756. https://doi.org/10.1007/s00227-010-1602-6

Erlandsson J, McQuaid CD, Stanczak S (2011) Recruit/algal interaction prevents recovery of overexploited mussel beds: indirect evidence that post-settlement mortality structures mussel populations. Estuar Coast Shelf Sci 92:132-139. https://doi. org/10.1016/j.ecss.2010.12.028

Fredriksen S, Christie H, Boström C (2004) Deterioration of eelgrass (Zostera marina L.) through destructive grazing by the gastropod Rissoa membranacea (J. Adams). Sarsia 89:218-222. https://doi. org/10.1080/00364820410005593

Frigstad H, Andersen T, Hessen DO, Jeansson E, Skogen M, Naustvoll L-J, Miles MW, Johannessen T, Bellerby RG (2013) Long-term trends in carbon, nutrients and stoichiometry in Norwegian coastal waters: evidence of a regime shift. Prog Oceanogr 111:113-124. https://doi.org/10.1016/j.pocean.2013.01.006

Gjøsæter J, Paulsen Ø (2004) Strandnotundersøkelser på Skagerrakkysten 2003. Havforskningsinstituttet, Report (In Norwegian)

Gorgula SK, Connell SD (2004) Expansive covers of turf-forming algae on human-dominated coast: the relative effects of increasing nutrient and sediment loads. Mar Biol 145:613-619. https:// doi.org/10.1007/s00227-004-1335-5

Halvorsen KT, Larsen T, Sørdalen TK, Vøllestad LA, Knutsen H, Olsen EM (2017) Impact of harvesting cleaner fish for salmonid aquaculture assessed from replicated coastal marine protected areas. Mar Biol Res 13:359-369. https://doi.org/10.1080/17451 000.2016 .1262042

Hansson I (1973) A new set of pH-scales and standard buffers for sea water. Deep-Sea Res 20:479-491. https://doi.org/10.1016/00117471(73)90101-0

Harley CDG, Hughes AR, Hultgren KM, Miner BG, Sorte CJB, Thornber CS, Rodriguez LR, Tomanek L, Williams SL (2006) The impacts of climate change in coastal marine systems. Ecol Lett 9:228-241. https://doi.org/10.1111/j.1461-0248.2005.00871.x

Heck KL, Pennock JR, Valentine JF, Coen LD, Sklenar SA (2000) Effects of nutrient enrichment and small predator density on seagrass ecosystems: an experimental assessment. Limnol Oceanogr 45:1041-1057

Jackson JBC, Kirby MX, Berger WH, Bjorndal KA, Botsford LW, Bourque BJ, Bradbury R, Cooke R, Erlandson J, Estes JA, Hughes TP, Kidwell S, Lange CB, Lenihan HS, Pandolfi JM, Peterson CH, Steneck RS, Tegner MJ, Warner R (2001) Historical overfishing and the recent collapse of coastal ecosystems. Science 293:629638. https://doi.org/10.1126/science.1059199

Karez R, Engelbert S, Kraufvelin P, Pedersen MF, Sommer U (2004) Biomass response and changes in composition of ephemeral macroalgal assemblages along an experimental gradient of nutrient enrichment. Aquat Bot 78:103-117. https://doi.org/10.1016/j. aquabot.2003.09.008

Korpinen S, Jormalainen V, Honkanen T (2007) Effects of nutrients, herbivory, and depth on the macroalgal community in the rocky sublittoral. Ecology 88:839-852 
Kraufvelin P (1999) Baltic hard bottom mesocosms unplugged: replicability, repeatability and ecological realism examined by multivariate techniques. J Exp Mar Biol Ecol 240:229-258. https://doi. org/10.1016/S0022-0981(99)00061-1

Kraufvelin P (2007) Responses to nutrient enrichment, wave action and disturbance in rocky shore communities. Aquat Bot 87:262-274. https://doi.org/10.1016/j.aquabot.2007.06.011

Kraufvelin P, Christie H, Olsen M (2002) Littoral macrofauna (secondary) responses to experimental nutrient addition to rocky shore mesocosms and a coastal lagoon. Hydrobiologia 484:149-166. https://doi.org/10.1007/978-94-017-3190-4_13

Kraufvelin P, Salovius S, Christie H, Moy FE, Karez R, Pedersen MF (2006a) Eutrophication-induced changes in benthic algae affect the behaviour and fitness of the marine amphipod Gammarus locusta. Aquat Bot 84:199-209. https://doi.org/10.1016/j.aquab ot.2005.08.008

Kraufvelin P, Moy FE, Christie H, Bokn TL (2006b) Nutrient addition to experimental rocky shore communities revisited: delayed responses, rapid recovery. Ecosystems 9:1076-1093. https://doi. org/10.1007/s10021-005-0188-1

Kraufvelin P, Ruuskanen AT, Nappu N, Kiirikki M (2007) Winter colonisation and succession of filamentous macroalgae on artificial substrates and possible relationships to Fucus vesiculosus settlement in early summer. Estuar Coast Shelf Sci 72:665-674. https ://doi.org/10.1016/j.ecss.2006.11.029

Kraufvelin P, Lindholm A, Pedersen MF, Kirkerud LA, Bonsdorff E (2010) Biomass, diversity and production of rocky shore macroalgae at two nutrient enrichment and wave action levels. Mar Biol 157:29-47. https://doi.org/10.1007/s00227-009-1293-z

Kraufvelin P, Svensson F, Fredriksson R, Bergström L, Karlsson M, Wennhage H, Wikström A, Bergström U (2017) Inventering och modellering av fisk- och kräftdjurssamhällen i Kosterhavets nationalpark. Länsstyrelsen Västra Götaland, Naturavdelningen, Rapportnr: 2017:22. ISSN: 1403-169X (in Swedish with English summary)

Kraufvelin P, Pekcan-Hekim Z, Bergström U, Florin A-B, Lehikoinen A, Mattila J, Arula T, Briekmane L, Brown EJ, Celmer Z, Dainys J, Jokinen H, Kääriä P, Kallasvuo M, Lappalainen A, Lozys L, Möller P, Orio A, Rohtla M, Saks L, Snickars M, Støttrup J, Sundblad G, Taal I, Ustups D, Verliin A, Vetemaa M, Winkler H, Wozniczka A, Olsson J (2018) Essential coastal habitats for fish in the Baltic Sea. Estuar Coastal Shelf Sci 204:14-30. https://doi.org/10.1016/j. ecss.2018.02.014

Kristiansen S, Paasche E (1982) Nitrogen nutrition of the phytoplankton in the Oslofjord. Estuar Coast Shelf Sci 14:237-249. https://doi. org/10.1016/S0302-3524(82)80014-5

Lewis LS, Anderson WW (2012) Top-down control of epifauna by fishes enhances seagrass production. Ecology 93:2746-2757

Masterson P, Arenas FA, Thompson RC, Jenkins SR (2008) Interaction of top down and bottom up factors in intertidal rockpools: effects on early successional macroalgal community composition, abundance and productivity. J Exp Mar Biol Ecol 363:12-20. https://doi. org/10.1016/j.jembe.2008.06.001

Micheli F, Heiman KW, Kappel CV, Martone RG, Sethi SA, Osio GC, Fraschetti S, Shelton AO, Tanner JM (2016) Combined impacts of natural and human disturbances on rocky shore communities. Ocean Coast Manage 126:42-50

Moksnes PO, Gullström M, Tryman K, Baden S (2008) Trophic cascades in a temperate seagrass community. Oikos 117:763-777. https://doi. org/10.1111/j.0030-1299.2008.16521.x

Moy FE, Christie H (2012) Large-scale shift from sugar kelp (Saccharina latissima) to ephemeral algae along the south and west coast of Norway. Mar Biol Res 8:309-321. https://doi.org/10.1080/17451 000.2011 .637561

Moy F, Alve E, Christie H, Helland A, Magnusson J, Steen H, Tveiten L, Åsen PA (2007) Statusrapport nr.2 fra Sukkertareprosjektet. Sugar kelp project: Status report no 2. SFT report TA-2232/2007, NIVA report 5344: $60 \mathrm{pp}$ (in Norwegian)

Nilsson J, Engkvist R, Persson LE (2004) Long-term decline and recent recovery of Fucus populations along the rocky shores of southeast Sweden, Baltic Sea. Aquat Ecol 38:587-598. https://doi. org/10.1007/s10452-004-5665-7

Noël LM-LJ, Griffin JN, Thompson RC, Hawkins SJ, Burrows MT, Crowe TP, Jenkins SR (2010) Assessment of a field incubation method estimating primary productivity in rockpool communities. Estuar Coast Shelf Sci 88:153-159. https://doi.org/10.1016/j. ecss.2010.03.005

Norderhaug KM, Christie H, Fosså JH, Fredriksen S (2005) Fish-macrofauna interactions in a kelp (Laminaria hyperborea) forest. J Mar Biol Assoc UK 85:1279

O'Connor NE, Crowe TP, McGrath D (2006) Effects of epibiotic algae on the survival, biomass and recruitment of mussels, Mytilus L. (Bivalvia: Mollusca). J Exp Mar Biol Ecol 328:265-276. https:// doi.org/10.1016/j.jembe.2005.07.013

Olsen EM, Halvorsen KT, Larsen T, Kuparinen A (2018) Potential for managing life history diversity in a commercially exploited intermediate predator, the goldsinny wrasse (Ctenolabrus rupestris). ICES J Mar Sci. https://doi.org/10.1093/icesjms/fsy195

Östman Ö, Eklöf J, Eriksson BK, Olsson J, Moksnes P-O, Bergström U (2016) Top-down control as important as nutrient enrichment for eutrophication effects in North Atlantic coastal ecosystems. J Appl Ecol 53:1138-1147. https://doi.org/10.1111/1365-2664.12654

Oviatt CA, Keller AA, Sampou PA, Beatty LL (1986) Patterns of productivity during eutrophication: a mesocosm experiment. Mar Ecol Prog Ser 28:69-80

Pauly D, Christensen V, Dalsgaard J, Froese R, Torres F (1998) Fishing down marine food webs. Science 279:860-863. https://doi. org/10.1126/science.279.5352.860

Pedersen MF, Borum J (1996) Nutrient control of algal growth in estuarine waters. Nutrient limitation and the importance of nitrogen requirements and nitrogen storage among phytoplankton and species of macroalgae. Mar Ecol Prog Ser 142:261-272. https://doi. org/10.3354/meps142261

Perez KT (1995) Role and significance of scale to ecotoxicology. In: Cairns J, Niederlehner BR (eds) Ecological toxicity testing: scale, complexity and relevance. Lewis Publishers, CRC Press, Boca Raton, pp 49-72

Råberg S, Berger-Jönsson R, Björn A, Granéli E, Kautsky L (2005) Effects of Pilayella littoralis on Fucus vesiculosus recruitment: implications for community composition. Mar Ecol Prog Ser 289:131-139. https://doi.org/10.3354/meps289131

Rothäusler E, Jormalainen V (2016) Eutrophication and the challenge of changing biotic interactions. In: Ólafsson E (ed) Marine macrophytes as foundation species. CRC Press, Boca Raton, pp 179-200

Russell BD, Connell SD (2005) A novel interaction between nutrients and grazers alters relative dominance of marine habitats. Mar Ecol Prog Ser 289:5-11. https://doi.org/10.3354/meps289005

Scheffer M, Carpenter S, Foley JA, Folke C, Walker B (2001) Catastrophic shifts in ecosystems. Nature 413:591-596

Sieben K, Rippen AD, Eriksson BK (2011) Cascading effects from predator removal depend on resource availability in a benthic food web. Mar Biol 158:391-400. https://doi.org/10.1007/s00227-010-1567-5

Skiftesvik AB, Blom G, Agnalt AL, Durif CMF, Browman HI, Bjelland RM, Harkestad LS, Farestveit E, Paulsen OI, Fauske M, Havelin T, Johnsen K, Mortensen S (2014) Wrasse (Labridae) as cleaner fish in salmonid aquaculture - the Hardangerfjord as a case study. Mar Biol Res 10:289-300. https://doi.org/10.1080/17451000.2013.810760

Spencer M, Birchenough SNR, Mieszkowska N, Robinson LA, Simpson SD, Burrows MT, Capasso E, Cleall-Harding P, Crummy J, Duck C, Eloire D, Frost M, Hall AJ, Hawkins SJ, Johns DG, Sims DW, Smyth TJ, Frid CLJ (2011) Temporal change in UK marine 
communities: trends or regime shifts? Mar Ecol 32(s1):10-24. https ://doi.org/10.1111/j.1439-0485.2010.00422.x

Tully O, Daly P, Lysaght S, Deady S, Varian SJA (1996) Use of cleanerwrasse (Centrolabrus exoletus (L.) and Ctenolabrus rupestris (L.)) to control infestations of Caligus elongatus Nordmann on farmed Atlantic salmon. Aquaculture 142:11-24. https://doi. org/10.1016/0044-8486(95)01245-1

Underwood AJ (1997) Experiments in ecology: their logical design and interpretation using analysis of variance. Cambridge University Press, Cambridge

Underwood AJ, Chapman MG (1997) GMAV5 for Windows. University of Sydney, Sydney

Valiela I, McClelland J, Hauxwell J, Behr PJ, Hersh D, Foreman K (1997) Macroalgal blooms in shallow estuaries: controls and ecophysiological and ecosystem consequences. Limnol Oceanogr 42:1105-1118

Wahl M, Jormalainen V, Eriksson BK, Coyer JA, Molis M, Schubert H, Dethier M, Karez R, Kruse I, Lenz M, Pearson G, Rohde S,
Wikström S, Olsen JL (2011) Stress ecology in Fucus: abiotic, biotic and genetic interactions. Adv Mar Biol 59:37-106. https:// doi.org/10.1016/B978-0-12-385536-7.00002-9

Wallentinus I (1984) Comparisons of nutrient uptake rates for Baltic macroalgae with different thallus morphologies. Mar Biol 80:215-225. https://doi.org/10.1007/BF02180189

Worm B, Lotze HK, Sommer U (2000) Coastal food web structure, carbon storage and nitrogen retention regulated by consumer pressure and nutrient loading. Limnol Oceanogr 45:339-349

Worm B, Lotze HK (2006) Effects of eutrophication, grazing, and algal blooms on rocky shores. Limnol Oceanogr 51:569-579

Publisher's Note Springer Nature remains neutral with regard to jurisdictional claims in published maps and institutional affiliations. 